\title{
ENVIRONMENTAL DECAY AND THE ILLEGAL MARKET IN E-WASTE FROM A EUROPEAN PERSPECTIVE: CURRENT PROBLEMS AND FUTURE DIRECTIONS ${ }^{\dagger}$
}

\author{
GIADA DALLA GASPERINA ${ }^{\dagger \dagger}$ \\ Ph.D. Candidate in International Studies \\ School of International Studies, University of Trento (Italy) \\ giada.dallagasperina@sis.unitn.it
}

Received: September 27th 2010 / Accepted: November 9th 2010

\begin{abstract}
In the last decade, the growth in electronics production and consumption has been coupled with an increase in the illegal export of electrical and electronic waste (or "ewaste") beyond the borders of the European Union (EU). Shipped to illegal recycling facilities in less industrialized countries, e-waste is a severe threat to the integrity of local environments and a potential source of ecosystem and biodiversity loss. Although the extent of the damage caused by e-waste pollution is unknown, scientific studies have warned of the perils of hazardous substances, which are released during primitive e-waste recycling activities in countries such as China, Ghana and Nigeria.

Drawing insights from the scientific literature, this paper illustrates how the problem of ewaste pollution is intrinsically linked to the issue of biodiversity and ecosystem degradation. In particular, it argues that much greater attention should be paid to the EU Directives on Waste Electrical and Electronic Equipment (WEEE) and the Restriction of the Use of Certain Hazardous Substances in Electrical and Electronic Equipment (RoHS) and to the proposals to recast the two Directives because of their potential to enhance
\end{abstract}


environmental protection globally. Nonetheless, underpinning this scrutiny is the contention that shortcomings in the EU legal framework on e-waste could ultimately affect the environment and biodiversity of less industrialized states.

RESUM: En la darrera dècada, el creixement de la producció i ús d'aparells electrònics ha donat origen a una exportació il·legal de residus elèctrics i electrònics des de la Unió Europea (UE) als països en desenvolupament. Enviats a llocs de reciclatge il·legal, els residus electrònics constitueixen una amenaça per a la integritat del medi ambient local i una causa potencial de pèrdua de biodiversitat i degradació de l'ecosistema. Malgrat que la gravetat dels danys causats pels residus electrònics al medi ambient en països com Xina, Ghana i Nigèria és desconeguda, estudis científics han posat de manifest que les substàncies que s'alliberen durant les operacions de reciclatge són extremadament tòxiques. En aquest estudi, que es basa en la bibliografia científica existent, s'examina la relació entre la contaminació provocada pels residus electrònics i el debilitament de l'ecosistema i de la biodiversitat. A més, l'article sosté que cal prestar una atenció especial a la legislació de la UE, particularment a la Directiva sobre restriccions a la utilització de determinades substàncies perilloses en aparells elèctrics i electrònics (RoHS), la Directiva sobre residus d'aparells elèctrics i electrònics (RAEE), i les propostes de refosa de les dues directives, perquè poden contribuir a millorar la protecció del medi ambient a escala mundial. Tanmateix, l'anàlisi es basa en l'argument que les deficiències existents en les directives RoHS i RAEE i les propostes de refosa podrien provocar, eventualment, una disminució severa i irreversible de la biodiversitat i la degradació del medi ambient en els estats menys industrialitzats.

RESUMEN: En la última década, el crecimiento de la producción y uso de aparatos electrónicos ha dado lugar a una exportación ilegal de residuos eléctricos y electrónicos de la Unión Europea (UE) a los países en desarrollo. Enviados a sitios de reciclaje ilegal, los 
residuos electrónicos constituyen una amenaza para la integridad del medio ambiente local y una causa potencial de pérdida de biodiversidad y degradación del ecosistema. Aunque se desconoce la gravedad de los daños ocasionados por los residuos electrónicos al medio ambiente en países como China, Ghana y Nigeria, estudios científicos han puesto de manifiesto que las sustancias que se liberan durante las operaciones de reciclaje son extremadamente tóxicas.

En este estudio, que se basa en la literatura científica existente, se examina la relación entre la contaminación provocada por los residuos electrónicos y el debilitamiento del ecosistema y de la biodiversidad. Además, el artículo sostiene que se debe prestar especial atención a la legislación de la UE, especialmente, a la Directiva sobre restricciones a la utilización de determinadas sustancias peligrosas en aparatos eléctricos y electrónicos (RoHS), a la Directiva sobre residuos de aparatos eléctricos y electrónicos (RAEE), y las propuestas de refundición de estas dos directivas, porque pueden contribuir a mejorar la protección del medio ambiente a nivel mundial. Pero este análisis se basa en el argumento que las deficiencias existentes en las directivas RoHS y RAEE y en las propuestas de refundición podrían, eventualmente, provocar una disminución severa e irreversible de la biodiversidad y la degradación del medio ambiente en los estados menos industrializados.

KEYWORDS: Electrical and electronic waste - Hazardous substances - Environmental pollution - RoHS and WEEE Directives

PARAULES CLAU: residus d'aparells elèctrics i electrònics — substàncies tòxiques contaminació ambiental — directives RoHS i RAEE

PALABRAS CLAVE: Residuos de aparatos eléctricos y electrónicos — Sustancias tóxicas — Contaminación ambiental — Directivas RoHS y RAEE 
Summary: I. Background and overview. II. The dangers of illegal trafficking in e-waste. 1. E-waste and hazardous substances in the backyard. 2. Waste pollution and biodiversity loss. III. The EU legal framework on e-waste: new avenues of environmental protection? 1. The WEEE Directive and the paradigm for e-waste prevention: a critical overview. 2. The RoHS Directive and the progress towards a non-toxic agenda: a critical overview. 3. Plugging gaps in the legal framework on e-waste: the proposals for recasting the WEEE and RoHS Directives. IV. Conclusions. V. Bibliography.

Over the past decade, transporting electrical and electronic waste (or "e-waste") illegally from the European Union (EU) to less industrialized countries has become a very lucrative business. ${ }^{1}$ Despite increasing regulatory efforts, the EU has not been able to reduce this upward trend. Sent to ill-equipped recycling facilities in developing states, electrical and electronic equipment (EEE) has proven to pose severe threats to the environment. ${ }^{2}$ Research demonstrates that the illegal market in e-waste has intensified environmental

\footnotetext{
$\dagger$ An earlier version of this paper was presented at the Eighth Annual Colloquium of the IUCN Academy of Environmental Law held on 13-17 September 2010, Ghent University, Ghent, Belgium.

it The author owes special thanks to Professor Michael Lynch for his support and suggestions. She would also like to thank the anonymous reviewers for their valuable comments.

1 E-waste (also called WEEE) is a general term used to describe waste generated from electrical and electronic equipment (or EEE), namely equipment which is "dependent on electric currents or electromagnetic fields in order to work properly". For the purposes of the present paper, the definition provided by EU legislation has been adopted. Art. 3(b), Directive on waste electrical and electronic equipment (the WEEE Directive); Directive 2002/96/EC of the European Parliament and of the Council of 27 January 2003 on waste electrical and electronic equipment (WEEE), [2003] OJ L37/24, 21.3.2008, as amended.

2 Illegal trafficking in e-waste is just one of many sources of pollution and environmental degradation generated by human activities. Similarly, widespread concern has been expressed about the problem of plastic debris in the oceans. In particular, studies have reported that plastic debris, accumulated in the Pacific Ocean, is increasing in size, thus constituting an enormous threat to marine wildlife. Indeed, as explained by José G.B. DERRAIK, "plastic litter[s]" and "small plastic pellets and granules" cause the death of sea animals and pollute "the marine food web" with polychlorinated biphenyls, which causes "reproductive disorders or death... and alter hormone levels" in wildlife. Evan N. EDINGER et al., also reveal that industrial waste has reduced the biodiversity of coral reefs by $40 \%$ to $70 \%$. See, on this point: ALIANI, S., GRIFFA, A., and MOLCARD, A. "Floating debris in the Ligurian Sea, north-western Mediterranean", Marine Pollution Bulletin, no. 46.9, 2003, pp. 1142-1149; DERRAIK, J.G.B., "The Pollution of the Marine Environment by Plastic Debris", Marine Pollution Bulletin, no.44.9, 2002, p. 846; EDINGER, E. N., JOMPA, J., LIMMON, G. V., WIDJATMOKO, W., and RISK, M. J., "Reef degradation and coral biodiversity in Indonesia: Effects of land-based pollution, destructive fishing practices and changes over time", Marine Pollution Bulletin, no. $36.8,1998$, p.629.
} 
pollution, creating an accumulation of hazardous substances in natural environments. ${ }^{3}$ Empirical evidence suggests that the uncontrolled dispersion of toxic pollutants, released by dumped waste or by the burning of waste on open fires, is a severe threat to the integrity of local ecosystems and wildlife. ${ }^{4}$

In response, researchers across the disciplines have examined the issue over the years. Discussions have revolved around the impact of the EU legislation that, in addition to the Basel Convention - an international treaty that establishes a global framework for controlling the transboundary trade in hazardous waste - regulates the shipment of waste across EU member states and to non-EU countries. ${ }^{5}$ In several other arenas, scholars have attempted to explore factors associated with the illegal trafficking in waste. On the one hand, criminologists have focused on the transnational dimension of this environmental crime and the involvement of organized crime syndicates while lawyers have examined the

3 The term "illegal market" has been extensively used in the criminological and legal literature to describe "places within which goods and services are exchanged whose production, sale and consumption are forbidden or strictly regulated by the majority of national states and/or by international legislation". Trafficking in drugs, armaments, and human beings are some examples of the illegal market opportunities. As noted by Pino ARLACCHI, "[i]llegal markets have much in common with their legal counterparts." And, as legal markets change over time, new illegal business opportunities have recently emerged. Among them, there is trade in endangered species, logging, and illegal trade in chlorofluorocarbons (CFCs). Illegal trafficking (or shipment) of waste is but one example of these new illegal activities that pose a threat to the environment. ARLACCHI, P., "Some Observations on Illegal Markets", in RUGGIERO V. (ed.), The New European Criminology: Crime and Social Order in Europe, Routledge, London, 1998, pp. 203- 204.

${ }^{4}$ SEPÚlVEDA, A., SCHLUEP, M., RENAUd, F. G., STREICHER, M., KUEHR, R., HAGELÜKEN, C., and GERECKE, A. C., "A review of the environmental fate and effects of hazardous substances released from electrical and electronic equipments during recycling: examples from China and India", Environmental Impact Assessment Review, no. 30.1, 2010, p. 39.

${ }^{5}$ An analysis of the Basel Convention is beyond the scope of the present investigation. Notwithstanding, it is worthy of mention that the transboundary movement of hazardous waste is permitted only if the waste will be managed in an environmentally sound way in the destination country. As reported by field studies, however, this procedure is doomed to failure because it is based on a self-reporting mechanism that is unable to function under national economic and regulatory asymmetries. Moreover, the Basel Ban, an amendment to the Basel Convention that would prohibit export of e-waste from developed to developing states, has not yet entered into force. In addition, developing states have difficulties in implementing international legislation to prevent transboundary movement of waste and despite the ratification rates, "the global environment is continuing to deteriorate." CROSSEN, T., "Multilateral environmental agreements and compliance continuum", Georgetown International Environmental Law Review, no. 16.3, 2004, p. 474. See also: WIDAWSKY, L., "In my backyard: how enabling hazardous waste trade to developing nations can improve the Basel Convention's ability to achieve environmental justice", Environmental Law, no. 38, pp. 577-625; WIDMER, R., OSWALD-KRAPF, H., SINHA-KHETRIWAL, D., SCHNELLMANN, M., and BOENI, H., "Global perspectives on e-waste", Environmental Impact Assessment Review, no. 25.5, 436-458. Basel Convention on the Control of Transboundary Movements of Hazardous Wastes and their Disposal (adopted 22 March 1989, entered into force 5 May 1992) (1989), 28 ILM 657. 
EU legislation and its asymmetries. ${ }^{6}$ On the other hand, biologists and toxicologists have studied the environmental implications associated with the release of pollutants from inorganic wastes. ${ }^{7}$ However, no studies have focused on the relationship between illegal trafficking in e-waste and environmental degradation. ${ }^{8}$ So far, it seems that researchers have disregarded scientific evidence that shows the dangers of hazardous substances and the devastating effects of e-waste pollution on the environment. Moreover, scholars have not yet considered the impact of the EU legislation on e-waste: namely, the EU Directive on the Restriction of the Use of Certain Hazardous Substances in Electrical and Electronic Equipment (RoHS), the EU Directive on Waste Electrical and Electronic Equipment (WEEE) and the recast proposals. ${ }^{9}$ The EU legislation on e-waste, which has introduced new standards in the fields of electronics manufacturing and e-waste management, could have an impact on biodiversity and ecosystem protection not only within the EU but also

6 See: ELLIOTT, L., "Combating Transnational Environmental Crime: 'Joined up' thinking about transnational networks", in K. Kagaspunta and I. H. Marshall (eds.), Eco-crime and Justice. Essays on Environmental Crime, Unicri, Turin, 2009, pp. 55-78; INTERPOL, "Electronic waste and organized crimeassessing the links", Trends in Organized Crime, no. 12, 2009, pp. 352-378; RUGGIERO, V., Organized and Environmental Crime in Europe. Offers that Can't Be Refused, Aldershot, Dartmouth, 1996.

${ }^{7}$ See: SÁNCHEZ-CHARDI, A., PEÑARROJA-MATUTANO, C., OLIVEIRA RIBEIRO C. A., and NADAL, J., "Bioaccumulation of metals and effects of landfill pollution in small mammals. Part II. The wood mouse, Apodemus sylvaticus", Chemosphere, no. 70, 2007, pp. 101-109.

${ }^{8}$ Nonetheless, a few researchers have recognized this problem and have pointed out that waste pollution may irreversibly harm wildlife and the environment. See, on this point: FREY, R. S., "The hazardous waste stream in the world-system", in P. S. Ciccantell, S. G. Bunker (eds.), Space and Transport in the World-system, Greenwood Press, Westport, 1998, p. 92; LYNCH, M. J., and MICHALOWSKI, J. R., Premier in Radical Criminology: Critical Perspective on Crime, Power and Identity, Criminal Justice Press, Monsey, 2006, p. 163. For the purposes of the present paper, biodiversity includes living and non-living organisms and their symbiotic interaction in the environment. Pursuant to a recognized definition, biodiversity or biological diversity "refers to the natural variety and variability among living organisms, the ecological complexes in which they naturally occur, and the ways in which they interact with each other and with the physical environment. Biodiversity has three different components: genetic, population/species, and community/ ecosystem". See: REDFORD, K. H, and RICHTER, B. D., "Conservation of biodiversity in a world of use", Conservation Biology, no. 13.6, 1999, p. 1246.

${ }^{9}$ Directive on the restriction of the use of certain hazardous substances in electrical and electronic equipment (The RoHS Directive); Directive 2002/95/EC of the European Parliament and of the Council of 27 January 2003 on the restriction of the use of certain hazardous substances in electrical and electronic equipment, [2003] OJ L 37/19, 13.2.2003, as amended; See: Directive 2002/96/EC (the WEEE Directive), note 1 above. 
beyond its borders. ${ }^{10}$ In particular, no studies have investigated whether the legal constraints of the EU legislation on e-waste could result in e-waste pollution posing a greater threat to the environment. The present analysis focuses on this facet of the legislation, and suggests further insights into the RoHS and WEEE Directives, because of their potential to enhance environmental protection globally.

The paper is divided into three sections. The first provides an overview of the issue of illegal waste trafficking, focusing specifically on the exportation of e-waste out of the EU to countries that are not members of the Organization for Economic Co-operation and Development (non-OECD countries). ${ }^{11}$ The second section explores the impact of e-waste pollution caused by primitive recycling activities, including water and soil contamination. To this end, details about the pollution potentials of e-waste and its effects on biodiversity are provided. The third section examines how legislation in the EU has been passed to protect the environment against the threat posed by e-waste handling, but has failed to adequately tackle the problem of e-waste pollution and management. In particular, attention is devoted to the RoHS Directive, the WEEE Directive and the recast proposals in order to problematize the challenges to effective environmental protection.

\section{BACKGROUND AND OVERVIEW}

The problem of transboundary pollution from toxic waste can be traced back to the 1980 s, when Europe and the U.S. witnessed an intensification of waste export to less industrialized

\footnotetext{
${ }^{10}$ CHRISTEN, K., "Government Watch: EU e-waste rules driving change in United States", Environmental Science and Technology, no. 37.1, 2003, p. 13; SANDS, P., "European Community environmental law: the evolution of a regional regime of international environmental protection", Yale Law Journal, no. 100.8, 1991, p. 2518; SELIN, H., VAN DEVEER, S. D., "Raising global standards: hazardous substances and e-waste management in the European Union", Environment: Science and Policy for Sustainable Development, no. 48.10, 2006, p. 14. Moreover, as scholars have argued, industrialized states, including the EU member states, have the economic and technological capacity to counteract environmental degradation. Therefore, they should invest their resources in order to prevent biodiversity loss within EU borders and in developing states. In addition, "developed states had benefited much more from economic and territorial exploitation: therefore, they should pay a higher prize for environmental protection." See, on this point: FRENCH, D., "Developing States and International Environmental Law: The Importance of Differentiated Responsibilities", International and Comparative Law Quarterly, no. 49.1, 2008, p. 49.

${ }^{11}$ LIPMAN, Z. "A Dirty Dilemma: The Hazardous Waste Trade”, Harvard International Review, no. 23.4, 2002, p. 69.
} 
countries. ${ }^{12}$ This intensification was the result of several factors, among which were the increase in the costs of the environmentally sound management of waste in developed states, world economic globalization and national regulatory and market asymmetries. ${ }^{13}$ These circumstances have provided the opportunity for corporations to transport waste across national borders in search of more lucrative places to externalize environmental costs. ${ }^{14}$ The human rights and environmental costs of this north-south trade have proven detrimental for the destination countries, since toxic cargoes originating from industrialized states have been repeatedly discharged in open fields or along seashores. ${ }^{15}$ In response, the Basel Convention was adopted in 1989 to regulate the transboundary movement of hazardous waste and introduce standards for the environmentally sound management of

12 For the purposes of the present paper, the terms waste and hazardous waste are derived from the EU legislation. Accordingly, "waste means any substance or object which the holder discards or intends or is required to discard", and "hazardous waste means waste which displays one or more of the hazardous properties listed in Annex III", as defined by Directive 2008/98/EC of the European Parliament and of the Council of 19 November 2008 on waste and repealing certain Directives, [2008] OJ L 312/3, art. 3(1) and art. 3(2). The deadline for transposition of Directive 2008/98/EC into domestic law by the EU Member States is December 12, 2010.

13 As clarified by Nikos PASSAS, "[i]ncreased awareness of serious health and environmental hazards in Western societies has led to legislation protecting the environment from industrial pollution." As a consequence, "[i]nstead of drastically reducing the risk of improper treatment of toxic waste, such regulation brought about asymmetries, which gave rise to an illegal market for waste disposal.... The large differences in the cost of disposal created incentives to engage in cross-border trade of waste exported to states that left particular substances unregulated." Hence, waste has begun to be exported to less industrialized countries, instead of being disposed of at the point of origin. In order to address this problem, the international community and, subsequently, national governments adopted regulations devoted to the control of the transboundary shipment in hazardous waste. PASSAS, N., "Lawful but awful: 'Legal Corporate Crimes", The Journal of Socio-Economics, no. 34.6, 2005, p. 774. See also GIBBS, C., Mc GARRELL, E. F. and AXELROD, M., "Transnational white-collar crime and risk", Criminology and Public Policy, no. 9.3, 2010, p. 544; MARTINEZ, C., "EEE Waste and the Basel Convention", in United Nations Conference on Trade and Development, Trade and Environment Review, UNCTAD, Geneva, 2006, p. 92; PASSAS, N., "Lawful but awful: Legal Corporate Crimes", Journal of Socio-Economics, 34.6, 2005, pp. 771-786; SCHMIDT, A., "Transboundary Movements of Waste Under EC Law: The Emerging Regulatory Framework", Journal of Environmental Law, no. 4.1, 1992, p. 58.

14 CLAPP, J., "The toxic waste trade with less-industrialised countries: economic linkages and political alliances", Third World Quarterly, no. 15.3, 1994, pp. 505-518.

${ }^{15}$ See GWAM, C. U., "Adverse Effects of the Illicit Movement and Dumping of Hazardous, Toxic, and Dangerous Wastes and Products on the Enjoyment of Human Rights", Florida Journal of International Law, no. 14, 2001, pp. 427- 474; MADAVA, T., "Illicit dumping of toxic wastes breach of human rights", Review of African Political Economy, no. 28.88, 2001, p. 289. It should also be noted that the effects of environmental pollution are found ubiquitously in nature. Pollution adversely affects human beings in both developed and less industrialized countries. See, on this point: ROBINSON, B. H., "E-waste: an assessment of global production and environmental impacts", Science of the Total Environment, no. 408.2, 2009, pp. 183-191. 
waste. ${ }^{16}$ More recently, the EU passed the European Waste Shipments Regulation (EC) No. 1013/2006 (WSR), thus amending the existing EU legislation on waste movement. ${ }^{17}$ This legislation is significant because not only has it implemented the Basel Convention, it has also prohibited the export of waste to non-OECD countries. ${ }^{18}$ Specifically, the WSR bans the export of waste destined for disposal and the export of hazardous waste destined for recovery to non-OECD countries. ${ }^{19}$ However, despite the regulatory efforts, the EU has

\begin{abstract}
${ }^{16}$ See note 5 above.
17 In 1984, the European Community (EC) established a harmonized system of control procedures for the shipment of waste among the EC member states (Council Directive 84/631/EEC of 6 December 1984 on the supervision and control within the European Community of the transfrontier shipment of hazardous waste, [1984] OJ L 326/31). Subsequently, the EC ratified the Basel Convention by Council Decision 93/98/EEC and Council Regulation (EEC) 259/93 on the supervision and control of shipments of waste within, into and out of the European Community [1993] OJ L 30/1, now repealed by Regulation (EC) No 1013/2006 (WSR); Regulation (EC) No 1013/2006 of the European Parliament and of the Council of 14 June 2006 on shipments of waste, [2006] OJ L190/1, 12.7.2006, as amended. JANS, J.H., and H. H. B., VEDDER, European Environmental Law, $3^{\text {rd }}$ ed., Europa Law Publishing, Groningen, 2008, p. 438.
\end{abstract}

${ }^{18}$ See: MAXIANOVA, K., "Shipment of Electronic Waste: Providing the Right Incentives through Regulation and Enforcement", Review of European Community and International Environmental Law, no. 17.3, 2008, p. 272.

19 Pursuant to the WSR, the export of waste destined for disposal is prohibited (art. 34, WSR) unless it takes place among the EC member states and countries that are members of the European Free Trade Association (EFTA) (i.e. Switzerland, Norway, Liechtenstein, Iceland). The export of hazardous waste destined for recovery is prohibited (art. 36, WSR) unless it takes place among the EC member states and OECD countries that apply the OECD C(2001)107. As explained by Karola MAXIANOVA, different requirements apply to recovery and disposal because recovery of waste, pursuant to the waste hierarchy defined by the EU legislation, is considered less detrimental than disposal. See, on this point: MAXIANOVA, K., note 18 above, p. 272. See also: CROWHURST, G., and DAVIDSON, S., "The New Regulation on Waste Shipment: Green List Controls", European Environmental Law Review, no. 16.8/9, 2007, pp. 223-226. Decision C(2001)107/ Final Organization for Economic Cooperation and Development concerning the Control of the Transboundary Movements of Wastes Destined for Recovery Operations, as amended by C(2004)20. Retrieved, June 15, 2009, from http://trade.ec.europa.eu/doclib/docs/2006/october/tradoc_130520.pdf. According to article 3(15) of Directive 2008/98/EC, "recovery means any operation the principal result of which is waste serving a useful purpose by replacing other materials which would otherwise have been used to fulfill a particular function, or waste being prepared to fulfill that function, in the plant or in the wider economy"; Directive 2008/98/EC, note 12 above. 
registered an increase in the illegal shipment of waste to non-OECD countries, principally to ports in Asia and Africa. ${ }^{20}$

More recently, a new challenge has arisen within society. Electrical and electronic equipment rapidly becomes obsolete and is discarded at an alarming rate and this has fuelled the illegal market in waste. ${ }^{21}$ Hence, increasing amounts of e-waste exported from the EU have been discarded illegally in developing states. ${ }^{22}$ Efforts to counteract this trend have been unsuccessful. Although the WSR dictates that e-waste shipments can only take place if they comply with the WSR provisions and if e-waste is sent to OECD countries, the ban on exports has not yielded the expected results. ${ }^{23}$ Its failure is largely due to the fact

${ }^{20}$ Illegal shipment of waste, generally understood as a violation of environmental law to which criminal
sanctions may apply (for this reason, also labeled as environmental crime), is a short term describing any
movement of waste across national boundaries in breach of EU and international law. The criminological
literature also uses the term illegal trafficking or illegal trade in waste. In this paper, the terms are used
synonymously in accordance with art. 2(35) of the Waste Shipment Regulation (EC) No. 1013/2006 (WSR),
note 17 above. See, on this point: EUROPEAN ENVIRONMENTAL AGENCY, Waste without borders in the
EU? Transboundary shipment of waste, Luxembourg, 2009, p. 11. Retrieved November 3, 2009, from http://
www.eea.europa.eu/publications/waste-without-borders-in-the-eu-transboundary-shipments-of-waste; NI, H.
G., ZENG, H., TAO, S., and ZENG, E. Y., "Environmental and human exposure to persistent halogenated
compounds derived from e-waste in China", Environmental Toxicology and Chemistry, no. 29.6, 2010, p. 1237.

21 BELLI, B., "Trash Talking", The Environmental Magazine, March/April 2007, p. 24; PUCKETT, J., BYSTER, L., WESTERVELT, S., GUTIERREZ, R., DAVIS, S., HUSSAIN, A., and DUTTA, M., Exporting harm: the high-tech trashing of Asia, Basel Action Network and Silicon Valley Toxics Coalition, Seattle, 2002. Retrieved November 4, 2009, from http://www. ban. org/E-waste/technotrashfinalcomp.pdf; SLADE, G., Made to break: technology and obsolescence in America, Harvard University Press, Cambridge, 2006; UNITED NATIONS UNIVERSITY, 2008 Review of Directive 2002/96/EC on Waste Electrical and Electronic Equipment: Final Report, Bonn, 2007, Retrieved May 4, 2009, from http://ec.europa.eu/ environment/waste/weee/pdf/final_rep_unu.pdf.

22 For instance, in the years 2004-2006, an inspection-project of the European Network for the Implementation and Enforcement of European Environmental Law (IMPEL) has revealed that, on average, approximately $30 \%$ of the cargoes subject to inspection at EU seaports, were illegal. Several of the seized shipments were about to take e-waste to non-OECD countries. See, on this point: SKINNER, I., BEYER, P., FARMER, A., Effective Enforcement Needs a Good Legal Base: the Final Report of the IMPEL Better Legislation Project, European Union Network for the Implementation and the Enforcement of Environmental Law, 2005. Retrieved November 2, 2009, from http://impel.eu/wp-content/uploads/2010/02/2003-13principles-better-legislation-FINAL-REPORT.pdf.

23 See, on this point: MAXIANOVA, K., note 18 above, p. 270; SANDER, K., SCHILLING, S., Transboundary shipment of waste electrical and electronic equipment/ electronic scrap - Optimization of material flows and control. Ökopol GmbH, Hamburg, 2010, p. 133. Retrieved July 26, 2010, from http:// www.basel.int/techmatters/e wastes/germany-report-18May2010.pdf. For details about the categories of electronic waste regulated by the EU legislation and the related shipment requirements, see: Correspondents' Guidelines No 4 on Classification of Waste Electrical and Electronic Equipment and Fly Ash from Coal-Fired Power Plants according to Annex IV. Part I. Note (c) of Regulation (EC) No 1013/2006 on Shipments of Waste. Retrieved August 10, 2010 from http://ec.europa.eu/environment/waste/shipments/pdf/ correspondents_guidelines4_en.pdf. 
that electronic appliances can be shipped to non-OECD countries if they go to the secondhand market for resale. ${ }^{24}$ These different rules on export are adequate for limited purposes such as re-using second-hand items, but when they are applied to the export of second-hand electronics to non-OECD countries, they become much harder to justify. As a consequence, the distinction between second-hand equipment and e-waste, instead of preventing illegal export, has proven to be highly criminogenic. Indeed, field studies have shown that companies have intentionally falsified export documents and labeled e-waste as secondhand material in order to circumvent the WSR ban. ${ }^{25}$

End-of-life electrical and electronic equipments are mainly sent to Africa, China or India where the demand for raw materials is high, environmental regulations are lax, and handling, recycling and disposal of e-waste is very profitable. ${ }^{26}$ Even though states that face the most severe threats from these illegal activities have passed legislation that bans the import of e-waste, they have not been able to counteract this trend. ${ }^{27}$ As documented by

${ }^{24}$ HUISMAN, W., and VAN ERP, J., "Smart Regulation and Enforcement of Illegal Disposal of Electronic Waste", Criminology and Public Policy, no. 9.3, 2010, p. 580.

25 CHEN, D., BI, X., ZHAO, J., CHEN, L., TAN, J., MAI, B., SHENG, G., FU, J., and WONG, M., "Pollution characterization and diurnal variation of PBDEs in the atmosphere of an e-waste dismantling region", Environmental Pollution, no. 157.3, 2009, p. 1051; CHIDI NNOROMA, I., and O., OSIBANJOB, "Sound management of brominated flame retarded (BFR) plastics from electronic wastes: state of the art and options in Nigeria", Resources, Conservation and Recycling, no. 52, 2008, pp. 1362-1372; GROSS, R., BUNKE, D., GENSCH, C., ZANGI, S., and MANHART, A., Study on Hazardous Substances in Electrical and Electronic Equipment, Not Regulated by the RoHS Directive, Öko- Institut e.V., Freiburg, 2008, p. 47. Retrieved July 3, 2010, from http://hse-rohs.oeko.info/fileadmin/user_upload/Documents/ Project description.pdf; HUISMAN, W., and J.,VAN ERP, note 24 above, p. 583; KUPER, J., and HOJSKIN, M., Poisoning the Poor. Electronic Waste in Ghana, Greenpeace Research Laboratories, Amsterdam, 2008, p. 10. Retrieved February 23, 2009, from http://www.greenpeace.org/raw/content/international/press/reports/ poisoning-the-poor-electonic.pdf; MANOMAIVIBOOL, P., "Extended producer responsibility in a nonOECD context: the management of waste electrical and electronic equipment in India", Resources, Conservation and Recycling, no. 53, 2009, pp. 136-144; SCHMIDT, A., note 13 above; UMESI, N. O., and ONYIA, S., "Disposal of e-wastes in Nigeria: an appraisal of regulations and current practices", International Journal of Sustainable Development and World Ecology, no. 15.6, 2008, pp. 565-573.

26 BABU, B. R., PARANDE, A. K., and BASHA, C.A., "Electrical and electronic waste: a global environmental problem", Waste Management and Research, no. 25.4, 2007, p. 311; INTERPOL, note 6 above, p. 358; SCHMIDT, A., note 13 above; SEPÚLVEDA, A., SCHLUEP, M., RENAUD, F. G., STREICHER, M., KUEHR, R., HAGELÜKEN, C., and GERECKE, A.C., note 4 above; SHINKUMA, T., and THI MINH HUONG, N., "The Flow of E-waste Material in the Asian Region and a Reconsideration of International Trade Policies on E-waste", Environmental Impact Assessment Review, no. 29.1, 2009, pp. 2531.

${ }^{27}$ HICKS, C., DIETMAR, R., and EUGSTER, M., "The recycling and disposal of electrical and electronic waste in China-legislative and market responses", Environmental Impact Assessment Review, no. 25.5, 2005, p. 463; MANOMAIVIBOOL, P., note 25 above. 
existing research, countries such as China and Nigeria have developed a thriving business of illegal "backyard recycling" facilities where workers employ primitive tools and methods to recover commercial materials and components from e-waste. ${ }^{28}$ In particular, studies report that "the processes and techniques used...during the recycling activities are often primitive and lack pollution control measures". ${ }^{29}$ E-waste is recycled in uncontrolled environments and the residual components are burned or discarded in open fields causing further release of toxic substances into the air, soil and water. ${ }^{30}$ Researchers highlight that "metal contamination arisen from primitive recycling and processing of electronic and computer wastes.... is an emerging global environmental issue, as these wastes have become one of the fastest growing waste types in some parts of the world". ${ }^{31}$

\section{THE DANGERS OF ILLEGAL TRAFFICKING IN E-WASTE}

Often overlooked by scholars, the environmental costs of electronics production and consumption are increasingly affecting peripheral ecosystems and could become important drivers of environmental deterioration and biodiversity loss. Although the extent of the

\footnotetext{
${ }^{28}$ BRIGDEN, K., LABUNSKA, I., SANTILLO, D., and JOHNSTON, P., Chemical Contamination at e-waste recycling and disposal sites in Accra and Korforidua, Ghana. Greenpeace Research Laboratories, Amsterdam, 2008. Retrieved February 23, 2009, from http://www.greenpeace.org/international/Global/ international/planet-2/report/2008/9/chemical-contamination-at-e-wa.pdf; HICKS, C., DIETMAR, R., and EUGSTER, M., note 27 above; ILES, A., "Mapping environmental justice in technology flows: Computer waste impacts in Asia", Global Environmental Politics, no. 4.4, 2004, pp. 76-107; LIU, H., ZHOU, Q., WANG, Y., ZHANG, Q., CAI, Z., and JIANG, G., "E-waste recycling induced polybrominated diphenyl ethers, polychlorinated biphenyls, polychlorinated dibenzo-p-dioxins and dibenzo-furans pollution in the ambient environment", Environment International, no. 34.1, 2008, p. 67; MANOMAIVIBOOL, P., note 25 above, p. 136.

29 WONG, C. S., WU, S. C., DUZGOREN-AYDIN, N. S., AYDIN, A., and WONG, M.H., "Trace metal contamination of sediments in an e-waste processing village in China", Environmental Pollution, no. 145.2, 2007, pp. 434-442.

30 SHINKUMA, T., and N., THI MINH HUONG, note 26 above; UMESI, N. O., and S., ONYIA, note 25 above.

${ }^{31}$ WONG, C. S., WU, S. C., DUZGOREN-AYDIN, N. S., AYDIN, A., and WONG, M. H., note 29 above, p. 434.
} 
damages caused by e-waste pollution is unknown, researchers from the natural sciences have been issuing warnings about the perils of hazardous substances and waste pollutions for years. In order to illustrate this point, this section first provides evidence about pollution at recycling facilities and the risk posed by heavy metals and other toxins released by ewaste.Then it summarizes the findings of the scientific community on the linkage between waste pollution and biodiversity loss.

\section{E-waste and hazardous substances in the backyard}

The causal link between e-waste pollution and biodiversity loss has yet to be confirmed. However, there is substantial reason to believe that the complex mix of environmental pollutants released during recycling and disposal of e-waste may irreversibly hamper the ecosystems of many developing states. Indeed, electrical and electronic equipments contain "more than 1000 different substances, many of which are toxic, such as lead, mercury, arsenic, cadmium...and flame retardants" that, if dispersed into the environment, contaminate groundwater and soil for decades. ${ }^{32}$ Also plastics in e-waste, when burned, release toxic pollutants, including dioxins and furans, which are known human carcinogens and persistent organic pollutants. ${ }^{33}$ Moreover, e-waste incineration in uncontrolled environments causes the formation of noxious pollutants. For instance, as explained by Morgan O'ROURKE, “copper in printed circuit boards and cables is a catalyst for dioxin and furan formation when flame retardants are burned". ${ }^{44}$ Also, polyvinyl chloride, commonly known as PVC, “is highly corrosive when burnt and also induces the formation

\footnotetext{
32 WIDMER, R., OSWALD-KRAPF, H., SINHA-KHETRIWAL, D., SCHNELLMANN, M., and BOENI, H., note 5 above, p.444; See also: ELECTRONICS TAKE BACK COALITION, The Problem With Electronics. Toxic Materials in Electronic Products. Retrieved August 15, 2010 from http://www.electronicstakeback.com/ problem/toxics_problem.htm.

33 As explained by field research, [b]urning e-waste may generate dioxins, furans, polycyclic aromatic hydrocarbons (PAHs), polyhalogenated aromatic hydrocarbons (PHAHs), and hydrogen chloride"; ROBINSON, B. H., note 15 above, p.183. See also: NI, H. G., ZENG, H., TAO, S., and ZENG, E.Y., note 20 above.

34 O'ROURKE, M., “Killer Computers: The Growing Problem of E-Waste”, Risk Management, no. 51.10, 2004, pp. 12- 18.
} 
of dioxins". ${ }^{35}$ Table 1 provides an inventory of some environmental contaminants, which are used in electrical and electronic equipments or are formed during the combustion of e-

\begin{tabular}{|c|c|}
\hline Pollutants & Related use in electronic and electric appliances \\
\hline $\begin{array}{l}\text { TBBA (tetrabromo-bisphenol-A) } \\
\text { PBB (polybrominated biphenyls) } \\
\text { PBDE (polybrominated diphenyl } \\
\text { ethers) }\end{array}$ & Fire retardants for plastics (thermoplastic components, cable insulation) \\
\hline PVC (polyvinyl chloride) & Cable insulation \\
\hline Arsenic & Small quantities in the form of gallium arsenide in light emitting diodes \\
\hline Barium & Fluorescent lamps, getters in cathode ray tubes (CRTs) \\
\hline Cadmium & $\begin{array}{l}\text { Rechargeable NiCd-batteries, fluorescent layer (CRT screens), printer inks and toners, } \\
\text { photocopying-machines (printer drums) }\end{array}$ \\
\hline Chromium VI & Data tapes, floppy-disks \\
\hline Lead & CRT screens, batteries, printed wiring boards, cathode tubes for monitors \\
\hline Mercury & $\begin{array}{l}\text { Fluorescent lamps that provide backlighting in LCDs, in some alkaline batteries and mercury } \\
\text { wetted switches }\end{array}$ \\
\hline Antimony & $\begin{array}{l}\text { In CRTs in old monitors, in printed circuit boards and as a fire retardant in electronic cable } \\
\text { coatings }\end{array}$ \\
\hline
\end{tabular}

waste, and details about their application in high-technologies. ${ }^{36}$

Recent studies have recognized the dangers posed by these hazardous substances at recycling sites in developing states. For instance, Greenpeace has carried out extensive research in Ghana, India and China, devoting attention to the problem of water and soil pollution arising from improper recycling and disposal of e-waste. ${ }^{37}$ Water and soil samples, which have been collected at recycling sites and analyzed in order to determine contaminant levels, show that "certain metals were present at concentrations over one

\footnotetext{
${ }^{35}$ UMESI, N. O., and S., ONYIA, note 25 above, p. 569.

36 Source: E-WASTE GUIDE, Hazardous Substances in e-Waste. A Knowledge Base for the Sustainable Recycling of E-Waste. Retrieved June 7, 2010 from http://ewasteguide.info/node/219; PUCKETT, J., BYSTER, L., WESTERVELT, S., GUTIERREZ, R., DAVIS, S., HUSSAIN, A., and DUTTA, M., note 21 above.

37 BRIGDEN, K., LABUNSKA, I., SANTILLO, D., and JOHNSTON, P., note 28 above; KUPER, J., and HOJSKIN, M., note 25 above.
} 
hundred times higher than typical background levels for soils, including the highly toxic metal lead". ${ }^{38}$

Similar studies have been undertaken in South-East China, India, Nigeria and Thailand where e-waste pollution has contaminated soil and aquifers. ${ }^{39}$ In particular, extensive research has been conducted in China, where toxins released by e-waste processing were found in plants, water and soil. ${ }^{40}$ As explained by Coby C. S. WONG et al., the "strong acid leaching operations along waterways" have heavily polluted the "riverine environment... [which] was heavily impacted by e-waste related activities". ${ }^{41}$ For instance, evidence indicates that the concentration of lead in the water samples taken from the Lijiang River (China) was 2,400 times higher than the levels of pollutants allowed by the World Health Organization (WHO) Drinking Water Guidelines. ${ }^{42}$ Rice crops adjacent to a recycling area in South-East China have also been analysed in order to investigate whether the occurrence of heavy metals could affect plant growth and yield in agricultural crops. These studies reveal that lead and cadmium in rice samples exceed the tolerable daily intakes according to food safety levels, and represent a potential threat to human health. ${ }^{43}$ In addition, scientists

\footnotetext{
${ }^{38}$ KUPER, J., and HOJSKIN, M., note 25 above, p. 8.

39 E.g. LIU, H., ZHOU, Q., WANG, Y., ZHANG, Q., CAI, Z., and G., JIANG, note 28 above, p. 72; MUNDADA, M. N., KUMAR, S., and SHEKDAR, A. V., "E-waste: a new challenge for waste management in India", International Journal of Environmental Studies, no. 61(3), 2004, pp. 265-279; MUENHOR, D., HARRAD, S., ALI, N., and COVACI, A. "Brominated flame retardants (BFRs) in air and dust from electronic waste storage facilities in Thailand”, Environment International, no. 36.7, 2010, pp. 690- 698; UMESI, N. O., and S., ONYIA, note 25 above.
}

40 As revealed by scholars, a major barrier to biodiversity conservation in China is originated by "[e] nvironmental pollution, [that] whether acid rain, waste disposal or via pesticides, threatens biodiversity either by poisoning wildlife species or destroying their key habitats and food chains." See, on this point: YU, X., "Biodiversity conservation in China: barriers and future actions", International Journal of Environmental Studies, no. 67.2, 2010, pp.117-126. For a more detailed map of areas in China where e-waste recycling takes place, see: LI, J., TIAN, B., LIU, T., LIU, H., WEN, X., and HONDA, S. "Status quo of e-waste management in mainland China”, Journal of Material Cycles and Waste Management, no. 8.1, 2006, p. 18.

41 WONG, C. S., DUZGOREN-AYDIN, N. S., AYDIN, A., and WONG, M.H., "Evidence of excessive releases of metals from primitive e-waste processing in Guiyu, China", Environmental Pollution, no. 148.1, 2007, p. 71.

42 HICKS, C., DIETMAR, R., and EUGSTER, M., note 27 above, p. 461; WORLD HEALTH ORGANIZATION, Guidelines for drinking-water quality. Health criteria and other supporting information, $2^{\text {nd }}$ Edition, Vol. 2, WHO, Geneva, 1996, pp. 285-98.

${ }^{43}$ FU, J., ZHOU, Q., LIU, J., LIU, W., WANG, T., ZHANG, Q., and JIANG, G., "High levels of heavy metals in rice (Oryza sativa L.) from a typical e-waste recycling area in southeast China and its potential risk to human health", Chemosphere, no. 71.7, 2008, pp. 1269-1275. 
have measured air pollution in areas adjacent to recycling sites. ${ }^{44}$ Duohong CHEN et al., report that "PBDE...concentrations are extraordinarily high in Guiyu [China], especially in the daytime" and the concentration of pentabromodiphenyl ether (PDE-47) is "even about 2 times higher than that in the dismantling hall of...[a] recycling electrical plant of Sweden". 45

In sum, the growing menace of e-waste pollution has been well recognized. These studies are significant because they provide empirical facts about pollution at the e-waste recycling sites to support the argument that e-waste could exacerbate the problem of environmental degradation and biodiversity loss. Despite these findings, knowledge about the effects of ewaste pollutants on the environment is limited and, as scholars have outlined, additional insights into the impact of e-waste pollution on wildlife and the ecosystem are urgently needed. ${ }^{46}$ Nonetheless, a wealth of information can be found elsewhere in numerous studies conducted by scientists, which provide evidence about pollution caused by heavy metals and other hazardous substances and their effects on human beings and animals. As recognized already, all substances which are known to interact with the natural environment have been found in high concentrations at recycling sites in developing states.

\section{Waste pollution and biodiversity loss}

Researchers from the natural sciences have provided important insights into the risks posed by man-made substances, documenting the complex interactions of toxins in the environment and the scale of ecosystem impact. ${ }^{47}$ In particular, the scientific literature has extensively examined the effects of heavy metals and chemicals, and demonstrated that

\footnotetext{
${ }^{44}$ CHEN, D., BI, X., ZHAO, J., CHEN, L., TAN, J., MAI, B., SHENG, G., FU, J., and WONG, M., note 25 above; WONG, M. H., WU, S. C., DENG, W. J., YU, X. Z., LUO, Q., LEUNG, A. O. W., WONG, C. S. C., LUKSEMBURG, W.J., and WONG, A.S., "Export of toxic chemicals - A review of the case of uncontrolled electronic-waste recycling”, Environmental Pollution, no. 149.2, 2007, pp. 131-140.

${ }^{45}$ CHEN, D., BI, X., ZHAO, J., CHEN, L., TAN, J., MAI, B., SHENG, G., FU, J., and WONG, M., note 25 above, p. 1053.

${ }^{46}$ FU, J., ZHOU, Q., LIU, J., LIU, W., WANG, T., ZHANG, Q., and JIANG, G., note 43 above, p. 1275.

${ }^{47}$ FREY, R. S., note 8 above.
} 
they cause severe health problems and harm to wildlife. As recognized by Lydia S. CORILL and James Edward HUFF, "[t]oxicity is the one characteristic that the metals arsenic, cadmium, lead, mercury, and zinc all have in common; each is capable of causing death and at lower doses can inhibit the development and growth of young marine animals". ${ }^{48}$ Existing studies, for instance, indicate that mercury, even in low quantities, "can cause neurological disorders" in human beings and, if released into the environment, mercury incorporates into deep sediment, enters the aquatic environment and "bioaccumulates in the aquatic food chain," thus causing long term damages. ${ }^{49}$ Moreover, scholars have discovered that lead damages the nervous and reproductive system of humans and wildlife and, as revealed by empirical studies, causes changes in the structure of chloroplasts of sampled biota. ${ }^{50}$ Research provides evidence that chromium (VI), "[i]n several aquatic and terrestrial species...induce[s] morphological alterations". 51

An endless list of substances, including lead, mercury, cadmium and flame retardants, all of which are in use in electronics manufacturing, are highly persistent because they are not degraded in the natural environment. Most of these toxins are also now recognized to be what are called endocrine disrupters because they interfere with the metabolic functions of

${ }^{48}$ CORRILL, L. S., and HUFF, J.E., "Occurrence, physiologic effects, and toxicity of heavy metals-arsenic, cadmium, lead, mercury, and zinc-in marine biota: an annotated literature collection", Environmental Health Perspectives, no.18, 1976, p. 181.

49 MUKHERJEE, A. B., ZEVENHOVEN, R., BRODERSEN, J., HYLANDER, L. D., and BHATTACHARYA, P., "Mercury in waste in the European Union: sources, disposal methods and risks", Resources, Conservation and Recycling, no. 42.2, 2004, p. 158. See also: HYLANDER, L. D., and GOODSITE, M.E., "Environmental costs of mercury pollution", Science of the Total Environment, no. 368.1, 2006, pp. 352-370; WONG, C. S., DUZGOREN-AYDIN, N. S., AYDIN, A., and WONG, M.H., "Sources and trends of environmental mercury emissions in Asia", Science of the Total Environment, no. 368.2-3, 2006, p. 650. According to a widely recognized definition, "Bioaccumulation (or bioconcentration) is the uptake of organic compounds by biota from either water or food. Many toxic organic chemicals attain concentrations in biota several orders of magnitude greater than their aqueous concentrations, and therefore, bioaccumulation poses a serious threat to both the biota of surface waters and the humans that feed on these surface-water species"; SMITH, J.A., WITKOWSKI, P.J., and FUSILLO, T.V., Manmade organic compounds in the surface waters of the United States - A review of current understanding, Geological Survey Circular, Denver, 1990, p. 92.

50 REBECHINI, H. M., and HANZELY, L., "Lead-induced ultrastructural changes in chloroplasts", $Z$. Pflanzenphysiol, no. 73, 1974, pp. 377-386.

${ }^{51}$ PRAKASH, C., "Chromium Accumulation and Toxicity in Aquatic Vascular Plants", The Botanical Review no. $70.3,2004$, p. 323. 
wildlife and humans, thus causing neurological and reproductive problems. ${ }^{52}$ Mechanisms of endocrine disruption in wildlife induced by waste pollution, for instance, have been shown by Guiomar ROTLLANT et al., who have examined the effects of dioxins on deep sea biota in the Mediterranean sea. They show that exposure to dioxins, among which are polychlorinated dibenzo-p-dioxins (PCDDs) and polychlorinated dibenzofurans (PCDFs), "cause[s] several endocrine, reproductive and developmental problems in animals" and threatens "the biodiversity of fragile and vulnerable ecosystems such as the deep-sea". 53 Similarly, researchers have documented the effects of endocrine disrupters, among which

\footnotetext{
52 According to a recognized definition, "an endocrine disrupter is an exogenous substance that causes adverse health effects in an intact organism, or its progeny, secondary to changes in endocrine function". See: PETERSEN, G., RASMUSSEN, D., and GUSTAVSON, K., Study on enhancing the Endocrine Disrupter priority list with a focus on low production volume chemicals, European Community - DG Environment, 2007, p. 15. Retrieved July 10, 2010 from http://ec.europa.eu/environment/endocrine/documents/ final_report_2007.pdf. Heavy metals, including lead, cadmium, mercury, and dioxins, furans, PCBs, and phthalates (used in PVC) have been identified as affecting the endocrine system. For a comprehensive list of substances recognized as endocrine disrupters, see: COLBORN, T., "Widespread Pollutants with Endocrinedisrupting Effects", Our Stolen Future. Retrieved July 20, 2010 from http://www.ourstolenfuture.com/Basics/ chemlist.htm. See also: OETKEN, M., BACHMANN, J., SCHULTE-OEHLMANN, U., and OEHLMANN, J., "Evidence for endocrine disruption in invertebrates", International Review of Cytology, no. 236, 2004, pp. 1-44; ROTLLANT, G., ABAD, E., SARDÀ, F., ÁBALOS, M., COMPANY, J.B., and RIVERA, J., "Dioxin compounds in the deep-sea rose shrimp Aristeus antennatus (Risso, 1816) throughout the Mediterranean Sea", Deep Sea Research Part I: Oceanographic Research Papers, no. 53.12, 2006, pp. 1895-1906.
}

53 As explained by Guiomar ROTLLANT et al., "Dioxin is a general term that describes a group of 210 chemical compounds that are highly persistent in the environment; they include the polychlorinated dibenzop-dioxins (PCDDs) and polychlorinated dibenzofurans (PCDFs). PCDD/Fs are fat-soluble and accumulate in animal tissues. They are among the more toxic anthropogenic contaminants formed as a by-product in combustion processes"; ROTLLANT, G., ABAD, E., SARDÀ, F., ÁBALOS, M., COMPANY, J.B., and RIVERA, J., note 52 above, p. 1895. 
are brominated flame retardants (BFRs), on the development of organs and the functioning of the hormonal system in wildlife. ${ }^{54}$

In brief, evidence shows that these substances have the potential to cause catastrophic forms of environmental decay. Until recently, however, few studies have focused on the relationship between e-waste and ecosystem degradation and biodiversity loss. Most of the existing research has investigated the effects of single contaminants on wildlife without considering that pollution generated from illegal disposal of waste may also cause adverse effects on local ecosystems. More recently, concerns about the effects of waste pollution in southern Italy have prompted researchers from the natural science to investigate the issue. ${ }^{55}$ These studies have used specific biota, known as bioindicators, to monitor the health of the environment and the possible adverse consequences for human health. As a result, researchers have documented that waste in areas of extensive illegal dumping has severely polluted the environment and caused "severe DNA damage" in biota. ${ }^{56}$ Other field studies present valuable evidence about contamination adjacent to illegal dumpsites. Alejandro SÁNCHEZ-CHARDI, Cristina PEÑARROJA-MATUTANO, Ciro Alberto OLIVEIRA

\footnotetext{
${ }^{54}$ As explained by Juliette LEGLER and Abraham BROUWER, BFRs "have received much attention due to their similarity with 'old' classes of organohalogenated compounds such as polychlorinated biphenyls (PCBs), in terms of their fate, stability in the environment and accumulation in human and wildlife." It is noteworthy to highlight that "[o]rganohalogenated compounds are some of the most prominent and persistent classes of environmental pollutants associated" and existing research shows that these BFRs "share some of the same mechanisms of action mediating their toxicity, in particular on endocrine systems"; LEGLER J., and A., BROUWER, "Are brominated flame retardants endocrine disruptors?", Environmental International, no. 29.6, 2003, p. 879. See also: CHIDI NNOROMA, I., and OSIBANJOB, O., note 25 above, p. 1366; COLBORN, T., VOM SAAL, F. S., and SOTO, A. M., "Developmental effects of EDCs in wildlife and humans", Environmental Health Perspective, no. 101, 1993, pp. 378-384; FOSSI, M. C., CASINI, S., and MARSILI, L., "Endocrine disruptors in Mediterranean top marine predators", Environmental Science and Pollution Research, no. 13.3, 2006, pp. 204-207; GROSS, M., DAGINNUS, K., DEVILLER, G.., DE WOLF, W., DUNGEY, S., GALLI, C., and GOURMELON, A., "Thresholds of toxicological concern for endocrine active substances in the aquatic environment", Integrated Environmental Assessment and Management, no. 6.1, 2010, pp. 2-11; MORF, L. S., TREMP, J., GLOOR, R., HUBER, Y., STENGELE, M., and, ZENNEGG, M., "Brominated flame retardants in waste electrical and electronic equipment: substance flows in a recycling plant", Environmental. Science and Technology, no. 39.22, 2005, p. 8691; OETKEN, M., BACHMANN, J., SCHULTE-OEHLMANN, U., and J., OEHLMANN, note 52 above, p. 32.
}

55 BASILE, A., SORBO, S., APRILE, G., CONTE, B., CASTALDO COBIANCHI, R., PISANI, T., and LOPPI, S., "Heavy metal deposition in the Italian "triangle of death" determined with the Moss Scorpiurum circinatum", Environmental Pollution, no. 157.8-9, 2009, pp. 2255-2260; MASELLI, V., POLESE, G., RIPPA, D., LIGRONE, R., KUMAR RASTOGI, R., and FULGIONE, D., "Frogs, sentinels of DNA damage induced by pollution in Naples and the neighbouring provinces", Ecotoxicology and Environmental Safety, no. 73.7, 2010, pp. 1525- 1529.

${ }^{56}$ MASELLI, V., POLESE, G., RIPPA, D., LIGRONE, R., KUMAR RASTOGI, R., and FULGIONE, D., note 55 above, p. 1527. 
RIBEIRO, and Jacint NADAL have explored the impact of illegal waste landfills on biota, using small mammals as environmental indicators. ${ }^{57}$ The study suggests that "long-term pollutant activities such as landfilling, may disturb or destroy ecosystems," and further insights into "the toxic effects of hazardous waste and landfill leachates in small mammals" are needed. ${ }^{58}$

\section{THE EUROPEAN UNION'S LEGAL FRAMEWORK ON E-WASTE: NEW AVENUES OF ENVIRONMENTAL PROTECTION?}

Environmental legislation in the European Union (EU) has recently undergone significant change. Despite increased market pressure and globalization, the EU has implemented compelling laws in the field of air pollution emissions and chemicals, thus acting as a driving force in putting environmental issues on the global agenda. ${ }^{59}$ Also, EU legislation on e-waste, namely the WEEE and the RoHS Directives, claims the same role domestically and internationally and, as some scholars have suggested, it has the potential to improve environmental standards globally. ${ }^{60}$ What is of particular interest is that the WEEE and the RoHS Directives, which have introduced new standards in the fields of electronics manufacturing and e-waste management, have had a significant impact beyond the EU borders since similar legislation has been adopted by non-EU countries. Indeed, the EU, by promoting environmental protection, has forced third countries to comply with the EU's requirements. However, although the EU legislation on e-waste has attracted considerable attention and approval, the legal constraints of the original texts have led to e-waste

\footnotetext{
57 SÁNCHEZ-CHARDI, A., PEÑARROJA-MATUTANO, C., OLIVEIRA RIBEIRO, C.A., and NADAL, J., note 7 above.

${ }^{58} I d .$, pp. 101, 107.

${ }^{59}$ LAIIDI, Z., EU foreign policy in a globalized world: normative power and social preferences, Routledge, Abingdon, 2008, p. 8.

${ }^{60}$ CHRISTEN, K., note 10 above; SELIN, H., and VAN DEVEER, S.D., note 10 above; EZROJ, A., "How the European Union's WEEE \& ROHS Directives can Help the United States Develop a Successful National E-waste Strategy", Virginia Environmental Law Journal, no. 28, 2010, pp. 45-72. See also: SANDS, P., note 10 above, p. 2518.
} 
pollution posing an increased threat to the environment, which could in turn "exacerbate... environmental problems in poorer states". ${ }^{61}$

Also the proposals for a recast of the WEEE and RoHS Directives, adopted by the European Commission in order to fulfill the obligations set forth by the WEEE and RoHS Directives themselves, appear not to play a major role in the minimization of e-waste and its toxicity to the environment. ${ }^{62}$ Addressing these shortcomings is an important step in recognizing that the EU legislation on e-waste could contribute to prevent e-waste pollution from becoming a mainstream source of environmental decay and biodiversity loss. The section below first summarizes the key provisions of the WEEE and RoHS Directives. Then it examines the problems that emerged during the implementation phase of the two Directives. And finally it scrutinizes the proposals for recasting the WEEE and RoHS Directives in order to discuss the potentials and shortcomings of the future legal framework on e-waste.

\section{The WEEE Directive and the paradigm for e-waste prevention: a critical overview}

The production and consumption of electrical and electronic equipment has risen dramatically in recent years. In response, the EU adopted the Directive on waste electrical and electronic equipment (WEEE) in 2003, with the aim of preventing the disposal of ewaste as unsorted municipal waste and encouraging the reuse, recycling and recovery of ewaste. Designed to reduce landfilling and incineration of e-waste, the WEEE Directive ultimately aims to "preserve, protect and improve the quality of the environment". ${ }^{63}$ The WEEE Directive has initiated a major regulatory reform in the electronics sector, since it

61 MCKENNA, A., "Computer waste: a forgotten and hidden side to the global information society", Environmental Law Review, no. 9, 2007, p. 125.

62 COMMISSION OF THE EUROPEAN COMMUNITIES, Proposal for a Directive on the European Parliament and of the Council on waste electrical and electronic equipment (WEEE) (Recast), COM (2008) 810 final, Brussels, 2008. Retrieved June 25, 2010 from http://eur-lex.europa.eu/LexUriServ/LexUriServ.do? uri=COM:2008:0810:FIN:en:PDF; COMMISSION OF THE EUROPEAN COMMUNITIES, Proposal for a Directive on the European Parliament and of the Council on the restriction of the use of certain hazardous substances in electrical and electronic equipment (Recast), COM (2008) 809 final, Brussels, 2008. Retrieved June 25, 2010 from. http://eur-lex.europa.eu/LexUriServ/LexUriServ.do?uri=COM:2008:0809:FIN:en:PDF.

${ }^{63}$ Recitals 1, Directive 2002/96/EC (the WEEE Directive), note 1 above. 
applies the extended producer responsibility principle (EPR). ${ }^{64}$ Consistent with the EPR principle, the WEEE Directive "shifts the entire responsibility of managing e-waste from the government to the original manufacturers of the product". ${ }^{65}$ Having implemented the polluter pays principle, the EPR should serve as an incentive to reduce environmental pollution originating from the disposal of e-waste. ${ }^{66}$

According to the WEEE provisions, producers have to finance collection, treatment, recovery and disposal of e-waste, placed on the market after 13 August 2005, and from both private and non-private (i.e. business users) households. For waste generated by private households, there are additional obligations. First, producers also have to finance the management of historic waste; that is to say, waste sold before 13 August $2005 .{ }^{67}$ Second, distributors and retailers are responsible for taking back e-waste (i.e. for organizing the collection of e-waste) from domestic consumers "at least free of charge", when analogous items are sold. ${ }^{68}$ Third, the WEEE Directive sets, as a separate collection target for household e-waste, the minimum amount of four kilograms per person per annum. Additionally, the WEEE Directive places the onus upon Member States "to ensure that

${ }^{64}$ According to the definition provided by the Organization for Economic Co-operation and Developments (OECD), the EPR is "a policy approach in which producers accept significant responsibility (financial and/or physical) for the treatment or disposal of post-consumer products." ORGANIZATION FOR ECONOMIC CO-OPERATION AND DEVELOPMENT, Extended Producer Responsibility. A Guidance Manual for Governments, Paris, OECD, 2003, p. 9; Recitals 1 and 8, Directive 2002/96/EC (the WEEE Directive), note 1 above; KHETRIWAL, D. S., KRAEUCHI, P., and WIDMER, R., "Producer responsibility for e-waste management: Key issues for consideration-Learning from the Swiss experience", Journal of Environmental Management, no. 90.1, 2009, p. 154; SANDER, E., TOJO, K., VERNON, N., SCHILLING, J., VAN ROSSEN, S., and GEORGE, C., The Producer Responsibility Principle of the WEEE Directive, European Community - DG Environment, 2007, p. 1. Retrieved August 3, 2010 from http://ec.europa.eu/environment/ waste/weee/pdf/final_rep_okopol.pdf.

${ }^{65}$ HOEVELER, J.A., "International approaches to dealing with electronic waste", New Zealand Journal of Environmental Law, no. 13, 2009, p. 146.

${ }^{66}$ BLEEKER A., "Does the Polluter Pay? The Polluter-Pays Principle in the Case Law of the European Court of Justice", European Energy and Environmental Law Review, no. 18.6, 2009, p. 292.

${ }^{67}$ Pursuant to art. 8 of the WEEE Directive, historic waste is e-waste generated by products sold before August 13, 2005; Directive 2002/96/EC (the WEEE Directive), note 1 above.

${ }^{68}$ Business users are obliged to bear the costs for the management of historic waste (i.e. waste generated by products sold before 13 August 2005), unless they replace the old item with analogous products. See: Art. 9.1, Directive 2002/96/EC (the WEEE Directive), note 1 above. 
producers and importers of electrical and electronic equipment set up a system to guarantee specified minimum levels of reuse, recycling and recovery of the WEEE". ${ }^{69}$

Despite its potentials, the WEEE Directive has also revealed shortcomings, which have led to questions about its overall efficacy and suitability to prevent e-waste from arising in the first place. What has been argued is that legal limitations could undermine the effectiveness of the WEEE Directive as a whole and lead to increased illegal shipment of e-waste. ${ }^{70}$ Overall, the EPR regime has led to major concerns. Although it has been identified as "one of the most significant developments in global environmental policy in the last decade," the EPR has faced several implementation problems and it is still unclear whether the mechanism through which producers can be held accountable is functioning effectively. ${ }^{71}$ One of the anomalies of the EPR is the fact that the WEEE Directive sets up a collective system to deal with financial responsibility, which may ultimately void the liability and responsibility of producers. Accordingly, the WEEE Directive authorizes manufacturers to co-finance e-waste management, dividing the costs on the basis of their market share; thus, it does not make manufacturers responsible for the management of the e-waste of their own electrical and electronic appliances. As Gerhard ROLLER and Martin FÜHR suggest, then, "influencing producer behavior by means of cost attribution is not taking place" because the costs for the management of discarded electronics are borne collectively and not individually. ${ }^{72}$ In particular, it has been observed over time that a system of collective sharing of responsibility does not create any financial incentive for producers to improve the design of their products.

A second gap in the legislative framework is the fact that the WEEE Directive has failed to create "a unified approach...to avoid internal market distortion and to establish standard

\footnotetext{
${ }^{69}$ JANS, J.H., and VEDDER, H.H.B., note 17 above, p. 435.

${ }^{70}$ MCKENNA, A., note 61 above, p. 127.

${ }^{71}$ SACHS, N., "Planning the funeral at the birth: extended producer responsibility in the European Union and the United States", Harvard Environmental Law Review, no. 30, p. 54; HOEVELER, J.A., note 65 above, p. 160 .

72 ROLLER, G., and FÜHR, M., "Individual Producer Responsibility: A Remaining Challenge under the WEEE Directive", Review of European Community and International Environmental Law, no. 17.3, 2008, p. 281.
} 
levels of environmental protection throughout the EU". ${ }^{73}$ This has occurred for two reasons. First, the Directive has an ambiguous scope and lacks clear definitions of the terms used, which has spawned controversies and led to different interpretations of the WEEE Directive across Member States. ${ }^{74}$ Second, since the WEEE Directive was adopted under article 175 of the European Community (EC) Treaty, it allows member states to go beyond its requirements and implement stricter provisions for the purposes of environmental protection. ${ }^{75}$ However, this has created discrepancies in the implementation of the WEEE, and hamperedg the effectiveness of the EU legislation. For instance, different national implementations of the EPR, different registration requirements by national authorities, different take back obligations and different interpretations of the scope of the WEEE have, at last, created additional costs and disparities for business operators. ${ }^{76}$

Another controversial issue is the frequent inconsistency in allocating the costs of e-waste management. For instance, the WEEE Directive sets different financial requirements for household and non-household waste. ${ }^{77}$ This, in turn, may further market and regulatory asymmetries because it induces producers to misclassify waste in order to avoid the additional costs imposed on household waste. ${ }^{78}$ Similarly, the WEEE Directive stipulates

\footnotetext{
${ }^{73}$ HOEVELER, J. A., note 65 above, p. 144.

74 For instance, article 3(b) stipulates that "components", "subassemblies", "consumables" are considered "part of the product at the time of discarding" but fails to define them. Moreover, there are not definitions of the terms "put on the market" (art. 8.2), and "not part of another type of equipment" (art. 2.1). And, in spite of further clarifications, Member States have interpreted these terms in different ways. BOGAERT, S. VAN ACOLEYEN, M., VAN TOMME, I., DE SMET, L., FLEET, D., and SALADO, R., Study on RoHS and WEEE Directives, Final Report, Arcadis RPA, Brussels, March 2008, pp. 189- 190. Retrieved May 23, 2009, from: http://ec.europa.eu/environment/waste/weee/pdf/rpa_study.pdf; VAN CALSTER, G., Handbook of EU Waste Law, Richmond Law \& Tax, Richmond, 2006, p. 147; WATSON, E., and CROWHURST, G., "The Implementation of the WEEE Directive in the UK - A critical Analysis", European Environmental Law Review, no. 16.6, 2007, p. 166.

75 VAN CALSTER, G., note 74 above, p. 147.

76 SANDER, E., TOJO, K., VERNON, N., SCHILLING, J., VAN ROSSEN, S., and GEORGE, C., note 64 above; WATSON, E., and CROWHURST, G., note 74 above, pp. 163- 175; UNITED NATIONS UNIVERSITY, note 21 above, p. 221.

${ }^{77}$ JANS, J.H., and VEDDER, H.H.B., note 17 above, p. 436.

${ }^{78}$ KHETRIWAL, D. S., KRAEUCHI, P., and WIDMER, R., note 64 above, p. 155; SANDER, E., TOJO, K., VERNON, N., SCHILLING, J., VAN ROSSEN, S., and GEORGE, C., note 64 above, p.193; UNITED NATIONS UNIVERSITY, note 21 above, p. 298.
} 
that producers in the market should "contribute...in proportion to their respective [market] share" to the costs for the management of historic household waste. ${ }^{79}$ As Dario MOCK and Grischa PERINO have shown, this requirement places an undue financial burden on new manufacturers entering the marketplace; thus, "if a firm enters a regulated market in 2006 or later it has to pay for the disposal of waste that incumbents produced in the past". ${ }^{80}$ Consequently, new firms could be discouraged from entering the market and "both technological progress... and growth of the economy at large" would be limited. ${ }^{81}$ Overall, the burdens imposed on producers, and in particular on small and medium enterprises (SMEs), are very high and, as many have argued, companies could be induced to externalize pollution costs and do their utmost to circumvent regulations rather than improve their environmental performance..$^{82}$

Furthermore, a crucial barrier to the successful implementation of the WEEE Directive is the lack of incentives for producers to improve their environmental performance and the absence of compliance measures. For example, research has shown that there are no "financial incentives for producers to go beyond the minimal legal obligations of collection target" for e-waste..$^{83}$ Because of this lack, there is a substantial risk that producers "would opt for the cheapest treatment solutions with potentially negative environmental consequences" and increased environmental pollution. ${ }^{84}$ Similarly, although the WEEE Directive recognizes the need for "innovations in design and development... [to] facilitate dismantling and recovery, reuse and recycling of WEEE", the Directive lacks binding

\footnotetext{
${ }^{79}$ Art. 8.3, Directive 2002/96/EC (the WEEE Directive), note 1 above.

${ }^{80}$ MOCK, D., and PERINO, G., "Wasting innovation: barriers to entry and European regulation on waste electronic equipment", European Journal of Law and Economics, no. 26.1, 2008, p. 2.

${ }^{81} I d .$, p. 3.

${ }^{82}$ NICOL, S., and THOMPSON, S., "Policy options to reduce consumer waste to zero: comparing product stewardship and extended producer responsibility for refrigerator waste", Waste management and Research, no. 25.3, 2007, p. 229; WATSON, E., and CROWHURST, G., note 74 above , p. 172.

${ }^{83}$ UNITED NATIONS UNIVERSITY, note 21 above, p. 297.

${ }^{84} I d$., p. 297.
} 
obligations for manufactures to design electronics so as to facilitate waste minimization. ${ }^{85}$ In particular, field studies have revealed that the EPR producer responsibility regime has had little effect on the development of eco-design. Besides this, it has been shown that incentives for the ecological design of products are ineffective, because the WEEE fails to reward "better environmental performance" of corporations. ${ }^{86}$

\section{The RoHS Directive and the progress towards a non-toxic agenda: a critical overview}

To minimize the impact of e-waste pollution on the environment and "protect human and animal health", in 2003 the European Community adopted the Directive on the Restriction of the Use of Certain Hazardous Substances in Electrical and Electronic Equipment (RoHS), which aims to improve the environmental footprint of electronics from their design phase. ${ }^{87}$ The RoHS Directive restricts the use of specified hazardous substances in electrical and electronic equipment that are known to cause major problems during their post-consumer life. Adopted under Article 95 of the EC Treaty, the Directive seeks to achieve a balance between the need for a high level of environmental protection and the need for harmonization of Member States' legislation by

\footnotetext{
${ }^{85}$ As explained by field studies, "[e]co-design is concerned with the development of products which are more durable, energy efficient, avoid the use of toxic materials and which can be easily disassembled for recycling." GOTTBERG, A., MORRIS, J., POLLARD, S., MARK-HERBERT, C., and COOK, M., "Producer responsibility, waste minimisation and the WEEE Directive: Case studies in eco-design from the European lighting sector", Science of the Total Environment, no. 359.1-3, 2006, p. 40; See also: BOGAERT, S. VAN ACOLEYEN, M., VAN TOMME, I., DE SMET, L., FLEET, D., and SALADO, R., note 74 above, p. 218; KELLNER, R., "Integrated Approach to Electronic Waste (WEEE) Recycling", Circuit World, no. 33.2, 2009, pp. 52- 58.

${ }^{86}$ NICOL, S., and THOMPSON, S., note 82 above, p. 229; PLAMBECK, E., and WANG, Q., "Effects of ewaste regulation on new product introduction", Management Science, no. 55.3, 2009, pp. 333-347; SACHS, N., note 71 above.

87 See: Recitals no. 8, Directive 2002/95/EC (the RoHS Directive), note 9 above. On the Precautionary Principle, see: DE SADELEER, N., and ROOSEVELT, A. F. D., "The Precautionary Principle in EC Health and Environmental Law", European Law Journal, no 12.2, 2006, p. 144.
} 
restricting the use of hazardous substances in electronics. ${ }^{88}$ In particular, it mandates the phase-out of lead, mercury, cadmium, hexavalent chromium, and of two categories of brominated flame retardants (BFRs), polybrominated biphenyls (PBB) and polybrominated diphenyl ethers (PBDE), from eight categories of electrical and electronic appliances regulated by the WEEE Directive, put on the market after 1 July $2006 .{ }^{89}$

The approach used by the RoHS Directive seems to strike a balance between the need to minimize hazardous substances in electronics and the need to accommodate industrial production. In this respect, the Directive recognizes that technological and economic changes cannot be achieved in a short period of time and industries need resources and long-term investments to identify substitutes for hazardous substances. ${ }^{90}$ For this reason, the ban on the use of the aforementioned substances is not absolute. ${ }^{91}$ First, the six banned substances can still be used, although below a maximum concentration level. ${ }^{92}$ Second, the RoHS Directive lists a number of applications, which are provisionally exempted from the requirements of the RoHS Directive to allow industries to conform with the RoHS

88 Hazardous substances are substances which have been classified as dangerous pursuant to Council Directive 67/548/EEC of 27 June 1967 on the approximation of laws, regulations and administrative provisions relating to the classification, packaging and labelling of dangerous substances, [1967] OJ 196/1, 16.8.1967, as amended. See note 12 above.

89 The electrical and electronic equipments that are subject to the requirements of the WEEE Directive are those appliances that fall under the categories set out in Annex IA of the WEEE Directive.

90 BOGAERT, S. VAN ACOLEYEN, M., VAN TOMME, I., DE SMET, L., FLEET, D., and SALADO, R., note 74 above, p. VI.

91 For instance, the RoHS Directive does not restrict the use of mercury in fluorescent lamps, which can therefore contain up to 5 milligrams of mercury per item. However, as reported by Min JANG, Seung Mo HONG, and Jae K. PARK, this quantity of mercury is sufficient to "fail the toxicity characteristics for mercury" when lamps are discarded. JANG, M., HONG, S. M., and PARK, J. K., "Characterization and recovery of mercury from spent fluorescent lamps", Waste management, no. 25.1, 2005, p. 6.

92 The concentration values are calculated by percentage weight in homogenous materials, which are parts or pieces of e-waste "that cannot be mechanically disjointed into different materials". See: EUROPEAN COMMISSION, Frequently Asked Questions on Directive 2002/95/EC on the Restriction of the Use of Certain Hazardous Substances in Electrical and Electronic Equipment (RoHS) and Directive 2002/96/EC on Waste Electrical and Electronic Equipment (WEEE), 2005, p. 17. Retrieved September 11, 2010, from: http:// ec.europa.eu/environment/waste/pdf/faq_weee.pdf; Commission Decision of 18 August 2005 amending Directive 2002/95/EC of the European Parliament and of the Council for the purpose of establishing the maximum concentration values for certain hazardous substances in electrical and electronic equipment, [2005] OJ L 214, 19/08/2005. 
requirements. ${ }^{93}$ Exemptions are granted, also upon request, if the substitution of materials is "technically or scientifically impracticable, or where the negative environmental, health and/or consumer safety impacts caused by substitution are likely to outweigh the environmental, health and/or consumer safety benefits thereof'. ${ }^{94}$ To guarantee that exemptions keep pace with scientific and technical progress, the RoHS Directive requires reexamination of each exemption every 4 years (or 4 years after a substance has been added to the Annex). ${ }^{95}$

Besides the 4-year review process for exemptions, the RoHS Directive introduces another mechanism of revision designed to expand its scope and ensure that environmental hazards are reduced or controlled. Accordingly, it stipulates that the European Commission shall monitor, "on the basis of scientific facts and taking the precautionary principle into account", whether additional hazardous substances should be added to the list of proscribed toxins. ${ }^{96}$ In order to fulfill these requirements, the Commission commissions studies to explore the potential risk associated with the use of hazardous substances exempted from the RoHS ban. Awaiting inclusion in the RoHS Directive, more than twenty substances have been classified as "[v]ery toxic to aquatic organisms," a potential source of "long-term

\footnotetext{
${ }^{93}$ In addition to these derogations, the RoHS "does not apply to spare parts for the repair, or to the reuse, of electrical and electronic equipment put on the market before 1 July 2006" (article 2.3, the RoHS Directive). Such exclusion is necessary to allow old equipment to be repaired; See: EUROPEAN COMMISSION, Frequently Asked Questions, note 92 above, p. 12.

${ }^{94}$ Article 5.1.(b), Directive 2002/95/EC (the RoHS Directive), note 9 above; It is worthy of note that, in 2008, the exemption granted for the use of Deca-BDE (decabromodiphenyl ether) in polymer applications was subject to judicial scrutiny by the European Court of Justice (ECJ). The ECJ annulled Commission Decision 2005/717/EC since the exemption was granted "without respecting the conditions laid down by Article 5(1)". See: Joined Cases C-14/06 \& C-295/06 European Parliament and Kingdom of Denmark v. Commission of the European Communities [2008] ECR I-01649; See also: HRISTEV, I., "RoHS and WEEE - The new European Directives: Do they work and why (or why not)? Current application and development in the EU and USA", European Environmental Law Review, no. 15.2, 2006, p. 72.

95 Article 5.1(c), Directive 2002/95/EC (the RoHS Directive), note 9 above. Pursuant to article 5.2 of the RoHS Directive, before exemptions are reviewed, the European Commission is obliged to consult manufacturers, environmental organizations, waste management companies, employee and consumer associations.

${ }^{96}$ Article 6, Directive 2002/95/EC (the RoHS Directive), note 9 above.
} 
adverse effects in the aquatic environment" and the possible causation of endocrine disruption. ${ }^{97}$

What is significant here is that the RoHS Directive has prompted non-EU manufacturers and also third countries to conform to the EU environmental standards. ${ }^{98}$ In particular, the RoHS Directive has brought "major changes in how electronics are produced globally" and has become essential for improving the ecological optimization of electronics production. ${ }^{99}$ However, although credited as one of the most important contributions to environmental protection in the waste policy field, the RoHS Directive has been widely criticized for its failure to provide substantial and effective standards of protection. Because of gaps and ambiguities in the legislative framework, the Directive has not received uniform implementation at the national level. ${ }^{100}$ Particularly, it has failed to establish a compliance procedure for product manufacturing and a market surveillance mechanism. This has ultimately affected trade and increased financial costs for firms, which have had to deal with different national requirements and asymmetries in the EU market. ${ }^{101}$

Other criticisms refer to the absence of incentives for innovation in new technologies and materials. Since the RoHS Directive does not specify an expiration date for exemptions but only establishes a 4-year monitoring mechanism, scholars have argued that innovation is slowed down because it is difficult "to ascertain how much effort and investment

\footnotetext{
${ }^{97}$ The substances under scrutiny are those classified as "hazardous," under the Council Directive 67/548/EEC, which are persistent, bioaccumulative, and toxic; GROSS, R., BUNKE, D., GENSCH, C., ZANGI, S., and MANHART, A., note 25 above, pp. 12-14; See note 88 above.

98 CHRISTEN, K., note 10 above; HICKS, C., DIETMAR, R., and EUGSTER, M., note 27 above, p. 463; SELIN, H., VAN DEVEER, S. D., note 10 above, p. 15.

${ }^{99}$ SACHS, N., note 71 above, p. 82.

100 BOGAERT, S. VAN ACOLEYEN, M., VAN TOMME, I., DE SMET, L., FLEET, D., and SALADO, R., note 74 above, p. 133, 134.

${ }^{101}$ WATSON, E., and CROWHURST, G., note 74 above, p. 164.
} 
companies will put into the development of alternative products". ${ }^{102}$ Likewise, progress has been hampered by the fact that the "industry has the choice between developing alternatives for certain products" or applying for an exemption. ${ }^{103}$ Studies have also revealed that the exemption procedure is inappropriate and financially burdensome since it takes a long time and prevents industries from investing in "research and development for new innovations". ${ }^{104}$ For these reasons, some scholars have suggested that exemptions should be granted for "time limited derogation for the specific aim of developing new products". 105

Furthermore, what is striking is that several toxic substances, which have the potential to adversely affect human health and the environment, have been left out of the Directive although they could be substituted with materials "available on the market", at least "for a large number of applications in EEE". ${ }^{106}$ In this respect, research has shown that "substitutes to phthalates, brominated flame retardants, and chlorine-containing plastics are available for... applications in EEE". 107

\footnotetext{
102 In this regard, it is worth mentioning that, during the review process of the exemption for the use of DecaBDE (decabromodiphenyl ether) in polymer applications, manufactures contended that it was difficult to find viable substitutes for Deca-BDE while, on the contrary, major industries had voluntarily substituted the substance because alternatives are available. See: PAKALIN, S., COLE, T., STEINKELLNER, J., NICOLAS, R., TISSIER,C., MUNN, S., and EISENREICH, S., Review on Production Process of Decabromodiphenyl Ether (DecaBDE) Used in Polymeric Applications in Electrical and Electronic Equipment amd Assessment of the Availability of Potential Alternatives to DecaBDE, European Chemicals Bureau, 2007, p. 16. Retrieved 2 July, 2010 , from: ht tp://e cb.jrc.it/documents/Existing-Chemicals/ Review_on_production_process_of_decaBDE.pdf; BOGAERT, S. VAN ACOLEYEN, M., VAN TOMME, I., DE SMET, $\bar{L}$., FLEET, $\bar{D}$., and R., SALADO, note 74 above, p. 179.
}

${ }^{103}$ BOGAERT, S. VAN ACOLEYEN, M., VAN TOMME, I., DE SMET, L., FLEET, D., and SALADO, R., note 74 above, p. 164.

${ }^{104}$ BOGAERT, S. VAN ACOLEYEN, M., VAN TOMME, I., DE SMET, L., FLEET, D., and SALADO, R., note 74 above, pp. 110, 150; GENSCH, C., ZANGL, S., and O., DEUBZER, Adaptation to Scientific and Technical Progress under Directive 2002/95/EC, Final Report, Öko-Institut e.V. \& Fraunhofer IZM, Freiburg, 2007, pp. 62- 64. Retrieved 2 July, 2010, from: http://ec.europa.eu/environment/waste/weee/pdf/rohs.pdf.

${ }^{105}$ BOGAERT, S. VAN ACOLEYEN, M., VAN TOMME, I., DE SMET, L., FLEET, D., and SAlAdO, R., note 74 above, p. 164.

106 GROSS, R., BUNKE, D., GENSCH, C., ZANGI, S., and MANHART, A., note 25 above, p. 216; ANDERSSON, E., Hazardous substances in electrical and electronic equipment (EEE)- expanding the scope of the RoHS directive, Project Report, Goteborg University \& Swedish Chemicals Inspectorate, 2005. Retrieved 2 June, 2010, from: http://circa.europa.eu/Public/irc/env/weee_2008/library?1=/characteristics/ hazardous_substances/_EN_1.0_\&a=d.

${ }^{107}$ GROSS, R., BUNKE, D., GENSCH, C., ZANGI, S., and MANHART, A., note 25 above, p. 216. 


\section{Plugging gaps in the legal framework on e-waste: the proposals for recasting the WEEE and RoHS Directives}

To keep pace with a fast changing electronics sector, the WEEE and the RoHS Directives underwent a comprehensive review and proposals for a recast of the two Directives were published by the European Commission in 2008. ${ }^{108}$ The revisions marked the rebirth of a new effort to curb the growing problem of e-waste pollution. The significance of these proposals lay in the fact that they recognize that changes to the current legal framework are needed. Overall, the aim of the proposals is to minimize administrative and financial burden for firms and simplify the legal framework. But more importantly, they intend to overcome the challenges of implementing the original legislation with a view to reducing pollution from e-waste and illegal shipments beyond the EU borders. ${ }^{109}$ However, following the EU Presidency and the European Parliament draft amendments to the proposals, it is likely that the recasts may take some time before becoming effective. Furthermore, although the recast proposals could play a crucial role in expanding the scope of the EU legislation on e-waste, there are still issues that have yet to be discussed. The

\footnotetext{
108 Pursuant to Art. 17.5 of the WEEE Directive, the European Commission has to prepare a report, for the European Parliament and the Council, summarizing the "experience of the application of...[the WEEE] Directive" "within five years after the entry into force of the Directive". The report has also to be "accompanied by proposals for revisions of the relevant provisions of...[the] Directive". Similarly, the RoHS Directive, pursuant to article 6, requires the European Commission to revise the RoHS provisions on the basis of new scientific facts and, additionally, to submit proposals for revisions of the proscribed substances and inclusion of two categories (cat. 8 and 9, medical devices and monitoring and control instruments). In order to accomplish its tasks, the Commission has requested consultants to conduct studies into the application of the WEEE and RoHS Directives at the national level and has interviewed key stakeholders.

109 In particular, the European Commission states: "[a] large part of the unreported, but collected, WEEE may either be treated in the EU without due environmental care or illegally shipped to developing countries where parts of the valuable material are recycled in ways dangerous to the health and environment, or dumped." See: COMMISSION OF THE EUROPEAN COMMUNITIES, Commission Staff Working Paper accompanying the Proposal for a Directive of the European Parliament and of the Council on waste electrical and electronic equipment (WEEE) (recast), SEC (2008) 2933, Brussels, 3.12.2008, p. 5. Retrieved September 15, 2009, from: http://eur-lex.europa.eu/LexUriServ/LexUriServ.do?uri=SEC:2008:2933:FIN:EN:PDF; COMMISSION OF THE EUROPEAN COMMUNITIES, Commission Staff Working Paper accompanying the Proposal for a Directive of the European Parliament and of the Council on the restriction of the use of certain hazardous substances in electrical and electronic equipment (recast), SEC (2008) 2930, Brussels, 3.12.2008. Retrieved September 15, 2009, from: http://eur-lex.europa.eu/LexUriServ/LexUriServ.do? uri=SEC:2008:2930:FIN:EN:PDF.
} 
section below examines the potentials and constraints of the Commission's proposals as the texts have progressed through the legislative process. ${ }^{110}$

\subsection{The proposed recast of the WEEE Directive}

The Commission's Proposal for a Directive on waste electrical and electronic equipment (the "WEEE Recast Directive") keeps the aim of the original WEEE Directive unchanged. ${ }^{111}$ To avoid divergences resulting from different interpretations of the WEEE Directive, the proposal amends previous definitions and introduces new requirements in order to "increase legal certainty and coherence with other Community legislation", and harmonize the implementation of the Directive throughout the Member States. ${ }^{112}$ Additionally, it proposes to introduce interoperable national registers for the registration of manufacturers. Such registers shall have equivalent formats, reporting obligations and fees, in order to facilitate the "exchange of information" between national registers and ultimately contribute to the strengthening of the EU market. ${ }^{113}$

To simplify the monitoring and the improvement of the collection targets, the WEEE Recast Directive also proposes to amend the target for the separate collection of electrical and electronic equipments. The current WEEE Directive stipulates a target of four kilograms to be calculated per inhabitant of each member state. The WEEE Recast Directive, however, proposes to calculate the target on the basis of the number of items placed on each domestic market in the two preceding years, which would make it possible

\footnotetext{
110 Progress towards agreement on the proposals for a recast of the WEEE and RoHS Directives has been slow. On the status of the legislative process, see: http://ec.europa.eu/prelex/rech_simple.cfm?CL=en.

111 COMMISSION OF THE EUROPEAN COMMUNITIES, Proposal for a Directive of the European Parliament and of the Council on waste electrical and electronic equipment (WEEE)(recast), note 62 above, p. 10 .

${ }^{112} I d .$, p. 10.

113 Article 16, the WEEE Recast Directive, note 62 above. It is noteworthy that the proposed register has been severely criticized for the implementation difficulties it would create. See on this: COUNCIL OF THE EUROPEAN UNION, Proposal for a Directive of the European Parliament and of the Council on waste electrical and electronic equipment (WEEE) - (recast). Progress Report, 10351/10. Brussels, 1.6.2010, p. 6. Retrieved September 5, 2010, from: http://register.consilium.europa.eu/pdf/en/10/st10/st10351.en10.pdf.
} 
to "take...into account the variations in EEE consumption in individual member states". 114 To minimize disposal of e-waste, it additionally proposes to introduce "targets for recovery and re-use/recycling, including for the re-use of whole appliances". ${ }^{115}$

Finally, the WEEE Recast Directive represents a more concerted effort to respond to the problem of illegal shipments of e-waste. ${ }^{116}$ Hence, it proposes to establish minimum inspection and monitoring requirements for improving law enforcement at the national level. ${ }^{117}$ In order to overcome difficulties arising from monitoring e-waste shipments, the WEEE Recast Directive requires member states to carry out cargo inspections to uncover ewaste disguised as second-hand appliances, or ready to be sent to landfills or improper recycling facilities. ${ }^{118}$

In spite of these positive developments, it seems that there are still some drawbacks to be overcome if the proposal is to be improved and new avenues for environmental protection provided. A crucial issue is the revision of the scope of the WEEE Directive. ${ }^{119}$ According to the proposal, Annex IA and IB (which contain the lists of the EEE categories and products covered by the WEEE Directive) of the current WEEE Directive would be deleted and the WEEE Recast Directive would instead refer to a fixed list of EEE included in Annex I of the RoHS Directive. The underlying justification for this change is to guarantee that the scope of both RoHS and WEEE Directives is defined on the basis of article 95 of

\footnotetext{
114 COUNCIL OF THE EUROPEAN UNION, Proposal for a Directive of the European Parliament and of the Council on waste electrical and electronic equipment (WEEE) - (recast). Progress Report, note 113 above, p. 2 .

115 COMMISSION OF THE EUROPEAN COMMUNITIES, Proposal for a Directive of the European Parliament and of the Council on waste electrical and electronic equipment (WEEE) (recast), note 62 above, p. 2.

116 EUROPEAN PARLIAMENT-COMMITTEE ON THE ENVIRONMENT, PUBLIC HEALTH AND FOOD SAFETY, Draft Report on the proposal for a directive of the European Parliament and of the Council on waste electrical and electronic equipment (WEEE), 2008/0241(COD), Brussels, 8.2.2010, p. 11. Retrieved September 11, 2010, from: http://www.europarl.europa.eu/meetdocs/2009_2014/documents/envi/pr/ 807/807375/807375en.pdf.
}

${ }^{117}$ Article 20, the WEEE Recast Directive, note 62 above.

118 Annex I, the WEEE Recast Directive, note 62 above.

119 Pursuant to article 2.2, the WEEE Recast Directive aims to align with the "requirements of Community legislation on safety and health requirements, and, on chemicals, in particular Regulation (EC)1907/2006 as well as of specific Community waste management or product design legislation". 
the EC Treaty, in order to ensure harmonization of the relevant national legislation and guarantee the proper functioning of the internal market. However, although this revision could enhance harmonization, it is doubtful that a fixed list of EEE would provide the right solution. Indeed, as shown by the EUROPEAN PARLIAMENT, "[a] binding, categorybased product list would have to be continually revised in order to reflect technical progress in the electrical and electronics market". ${ }^{120}$

A further problem that needs to be addressed is the fact that the WEEE Recast Directive extends producer responsibility for the management of domestic e-waste by requiring member states to "encourage producers to finance all the cost occurring for collection facilities for WEEE from private households". ${ }^{121}$ However, excessive costs imposed on the industry can lead to contradictory results. For instance, disproportionate costs imposed for the financing of household waste, as already indicated, can increase the risk that producers would falsely report e-waste as generated by non-domestic households. ${ }^{122}$ What is of even more concern is that the WEEE Recast Directive assigns all responsibility for e-waste management to producers, but fails to ascribe any responsibility to other market players, such as waste management companies and traders. But it is undeniable that, as the EUROPEAN ECONOMIC AND SOCIAL COMMITTEE has highlighted, "producers should not be held liable alone...[since] large flows of WEEE collected and treated outside the official WEEE systems and...many stakeholders, other than producers...can influence the volumes collected and recycled". ${ }^{123}$ Besides, the proposal, like the original WEEE Directive, does not introduce a system of individual producer responsibility, thus failing to establish an effective system of responsibility ascription.

120 EUROPEAN PARLIAMENT-COMMITTEE ON THE ENVIRONMENT, PUBLIC HEALTH AND FOOD SAFETY, Draft Report on the proposal for a directive of the European Parliament and of the Council on waste electrical and electronic equipment (WEEE), note 116 above, p. 11.

${ }^{121}$ Article 12.1, the WEEE Recast Directive, note 62 above.

122 EUROPEAN PARLIAMENT-COMMITTEE ON THE ENVIRONMENT, PUBLIC HEALTH AND FOOD SAFETY, Draft Report on the proposal for a directive of the European Parliament and of the Council on waste electrical and electronic equipment (WEEE), note 116 above, p. 14.

123 EUROPEAN ECONOMIC AND SOCIAL COMMITTEE, Opinion of the European Economic and Social Committee on the Proposal for a Directive of the European Parliament and of the Council on Waste electrical and electronic equipment (WEEE), [ 2009] OJ C 306/39, 16.12.2009. Retrieved September 3, 2010, from: http://eur-lex.europa.eu/LexUriServ/LexUriServ.do?uri=OJ:C:2009:306:0039:0041:EN:PDF. 


\subsection{The proposed recast of the RoHS Directive}

To address the first objectives of the RoHS Directive, the European Commission issued a "Proposal for a Directive on the restriction of the use of certain hazardous substances in electrical and electronic equipment" (the "RoHS Recast Directive") in order to amend its original scope and include two new product categories, which were not present in the earliest text of the WEEE Directive: category 8 (Medical Devices) and category 9 (Monitoring and Control Instruments). ${ }^{124}$ To achieve harmonization, the RoHS Recast Directive introduces new Annexes describing the scope of both the WEEE Recast and the RoHS Recast Directives. Annex I provides a list of product categories (which were originally listed in Annex IA of the WEEE Directive) and Annex II provides a mandatory list of electrical and electronic appliances for each category (which were originally listed in Annex IB of the WEEE Directive). This modification has been made to guarantee a harmonized implementation of both pieces of EU legislation throughout the member states so as to prevent trade barriers. Indeed, the RoHS Recast Directive, like the original legislation, has been adopted under article 95 of the EC Treaty, which aims to guarantee the proper functioning of the internal market. Accordingly, member states would not be allowed to depart from the requirements of the RoHS Recast Directive or to flesh out its scope, resulting in more uniform implementation of the legislation.

No new substances have been added to the list of the six hazardous substances currently proscribed by the RoHS Directive. ${ }^{125}$ Instead, the RoHS Recast Directive proposes an additional annex (Annex III), with four highly toxic substances identified for priority phase out. In this regard, it represents a fundamental change to the current revision procedure.

\footnotetext{
${ }^{124}$ Art. 4.3, the RoHS Recast Directive, note 62 above. As specified in the RoHS Recast Directive, the new clause will enter into force in different stages in order to allow the industry to adapt to the new requirements and make manufacturing adjustments. Moreover, exemptions for the new categories will be listed in a new annex (Annex VII).

${ }^{125}$ Annex IV of the RoHS Recast Directive lists the substances proscribed under RoHS and for each of them it specifies the maximum concentration limits permitted in homogeneous components of electrical and electronic appliances. The RoHS Recast Directive now also includes (article 3(1)) a definition of homogeneous materials.
} 
Article 4.7 of the RoHS Recast Directive requires that reviews (for possible inclusion or amendment) of the substances listed in Annex III and IV be carried out using the methodology defined in the EC Regulation on chemicals and their safe use (REACH). ${ }^{126}$ The rationale for this amendment is that it guarantees "consistency" and "coherency" with other EU procedures and reduces "unnecessary administrative costs". ${ }^{127}$

Similarly, the RoHS Recast Directive proposes two new amendments to the original text in order to strengthen the implementation of its provisions. First, it proposes that manufacturers can attest product conformity with the RoHS standards through an EC declaration of conformity and, subsequently, display the CE marking, as established for other Community products. ${ }^{128}$ Second, it proposes to introduce a market surveillance mechanism. This surveillance mechanism will ensure compliance with the RoHS requirements and prevent items containing the proscribed substances from entering the Community market due to the lack of monitoring. ${ }^{129}$

A significant change proposed is the amendment of the exemption procedure, which has been widely criticized for having failed to stimulate industrial innovation and research. According to the new exemption procedure proposed by the RoHS Recast Directive, exemptions are granted for a maximum period of 4 years (with possibility of renewal), so as

\footnotetext{
126 Regulation (EC) No 1907/2006 of the European Parliament and of the Council of 18 December 2006 concerning the Registration, Evaluation, Authorisation and Restriction of Chemicals (REACH), establishing a European Chemicals Agency, amending Directive 1999/45/EC and repealing Council Regulation (EEC) No $793 / 93$ and Commission Regulation (EC) No 1488/94 as well as Council Directive 76/769/EEC and Commission Directives 91/155/EEC, 93/67/EEC, 93/105/EC and 2000/21/EC, [2006] OJ L396/1, 30.12.2006.

127 COMMISSION OF THE EUROPEAN COMMUNITIES, Commission Staff Working Paper accompanying the Proposal for a Directive of the European Parliament and of the Council on the restriction of the use of certain hazardous substances in electrical and electronic equipment (recast), SEC (2008) 2930, Brussels, 3.12.2008, p. 18. Retrieved September 15, 2009, from: http://eur-lex.europa.eu/LexUriServ/LexUriServ.do? uri=SEC:2008:2930:FIN:EN:PDF; COMMISSION OF THE EUROPEAN COMMUNITIES, Proposal for a Directive of the European Parliament and of the Council on the restriction of the use of certain hazardous substances in electrical and electronic equipment (recast), note 62 above, p. 2.
}

128 Art. 7, RoHS Recast Directive, note 62 above. See also: Decision No 768/2008/EC of the European Parliament and the Council of 9 July 2008 on a common framework for the marketing of products, and repealing Council Decision 93/465/EEC, [2008] OJ L 218/82, 13.8.2008.

129 BOGAERT, S. VAN ACOLEYEN, M., VAN TOMME, I., DE SMET, L., FLEET, D., and SALADO, R., note 74 above, p. 131. Regulation (EC) No 765/2008 of the European Parliament and of the Council of 9 July 2008 setting out the requirements for accreditation and market surveillance relating to the marketing of products and repealing Regulation (EEC) No 339/93, [2008] OJ L 218/30, 13.8.2008. 
to encourage a phase out of the exempted applications of hazardous substances in electrical and electronic equipment.

The RoHS Recast Directive proposes some important amendments to the existing legal framework. Focusing primarily on harmonization, the future implementation of the proposal could ensure better enforcement of RoHS requirements and ultimately reduce the use of hazardous substances in EEE. However, the RoHS Recast Directive, like the original legislation, falls short of addressing fundamental issues. First, it still prescribes maximum concentration values in homogeneous materials for the six banned substances. ${ }^{130}$ The problem with the setting of concentration limits is that it could ultimately nullify or reverse the potential benefits generated with the phase out of the six banned toxic substances, since concentration limits do not take into account total amount of pollution, namely pollution levels measured on the basis of quantities of product categories placed on the market. Indeed, as researchers have suggested, the specification of concentration limits could "lead to situations where a product using lead in an amount just below the maximum concentration value but put on the market in large amounts is considered RoHS compliant". ${ }^{131}$ In turn, this would cause serious environmental problems and significant accumulation of pollutants, because it would allow on the EU market electrical and electronic appliances containing hazardous substances under the RoHS concentration limits but with a large market demand. ${ }^{132}$

Second, the RoHS Recast Directive does not include environmental protection among its objectives and does not take into account that the elimination of hazardous substances is essential to prevent increased e-waste pollution. ${ }^{133}$ For instance, the Commission proposal fails to make reference to the results of recent studies on the danger of hazardous

\footnotetext{
${ }^{130}$ Annex IV, the RoHS Recast Directive.

${ }^{131}$ GENSCH, C., ZANGL, S., and DEUBZER, O., note 104 above, p. 65.

${ }^{132} I d$.

133 COUNCIL OF THE EUROPEAN UNION, Proposal for a Directive of the European Parliament and of the Council on the restriction of the use of certain hazardous substances in electrical and electronic equipment - (RoHS) (recast). Progress Report, 10350/10, Brussels, June 2010. Retrieved October 12, 2010, from: http://register.consilium.europa.eu/pdf/en/10/st10/st10350.en10.pdf..
} 
substances awaiting inclusion in the Directive. ${ }^{134}$ The commissioned study recommended the phase out of such substances after having ascertained that "technically suitable, less harmful alternatives [are] available". ${ }^{135}$ Despite such warnings, it is striking that the RoHS Recast Directive not only fails to include details about the adverse environmental impact of the substances under scrutiny, it does not propose a voluntary phase-out clause for such substances either. ${ }^{136}$ Similarly, the proposal fails to encourage firms to develop innovation, since it does not provide any incentive for producers to voluntarily phase out hazardous substances from the manufacturing of electronics.

Third, what is of particular concern is that the RoHS Recast Directive has been remiss in its failure to integrate concerns for environmental protection. The proposal only provides for a short non-mandatory list of substances that most urgently require assessment, but it does not ban any new hazardous substances. ${ }^{137}$ Even more striking is that the European Commission, as outlined by the EUROPEAN PARLIAMENT, asserts "that the available data does not allow deciding on further restrictions of halogenated flame retardants". ${ }^{38}$ Conversely, the European Commission concludes that halogen-free flame retardants, which may be able to be used as substitutes, "do not present some of the hazards...such as, persistence, bioaccumulation or toxicity". ${ }^{139}$

\footnotetext{
134 EUROPEAN PARLIAMENT- COMMITTEE ON THE ENVIRONMENT, PUBLIC HEALTH AND FOOD SAFETY, Report on the Proposal for a Directive of the European Parliament and of the Council on the restriction of the use of certain hazardous substances in electrical and electronic equipment (recast), A7-0196/2010, 15.6.2008, p. 9. Retrieved July 30, 2010, from: http://www.europarl.europa.eu/sides/ getDoc.do?type $=$ REPORT\&reference $=$ A7-2010-0196\&language $=E N$

${ }^{135}$ GROSS, R., BUNKE, D., GENSCH, C., ZANGI, S., and MANHART, A., note 25 above,

136 EUROPEAN PARLIAMENT- COMMITTEE ON THE ENVIRONMENT, PUBLIC HEALTH AND FOOD SAFETY, Report on the Proposal for a Directive of the European Parliament and of the Council on the restriction of the use of certain hazardous substances in electrical and electronic equipment (recast), note 134 above, p. 9.

${ }^{137} I d$., p. 33. In particular, the RoHS Recast Directive makes no reference to the hazards posed by dioxin and furans formed during combustion, PVC and other substances identified as highly toxic to the environment.

${ }^{138} I d$., p. 74.

${ }^{139}$ COMMISSION OF THE EUROPEAN COMMUNITIES, Commission Staff Working Paper accompanying the Proposal for a Directive of the European Parliament and of the Council on the restriction of the use of certain hazardous substances in electrical and electronic equipment (recast), note above 127, p. 64.
} 
Because of these shortcomings, it seems that the proposal remains fundamentally at odds with the principles of environmental protection pursued by the EU and with the scientific understanding of environmental threat caused by e-waste pollution. In particular, since "a large portion... of [e-waste] is not disposed of and/or recycled within the EU" but it is sent to developing states, it is striking to see that the negative impact of these legal constraints could extend far beyond the EU frontiers. ${ }^{140}$ This is confirmed by the fact that many hazardous substances, which "continue to be used in new products" sold in the EU market, were found at recycling sites in China and Ghana. ${ }^{141}$

\section{CONCLUSIONS}

Recently, the growth in electronics manufacturing and consumption has been coupled with an increase in the export of electrical and electronic waste (or "e-waste") out of the European Union (EU). Shipped to illegal recycling sites in less-industrialized countries, ewaste has given rise to great concerns. Evidence shows that this illegal trade has intensified the pollution and deterioration of local environments in areas adjacent to recycling facilities. By analyzing soil and groundwater samples collected at recycling sites in China, India and Ghana, scholars have demonstrated high levels of contamination caused by unsafe recycling operations. So far, research assessing the impact of e-waste pollution in these areas has not examined the effects of heavy metals and other toxins, released from ewaste, on biodiversity. In spite of the data limitations, there are compelling reasons to fear

140 In particular, the study has suggested phasing out the following substances: tetrabromobisphenol-A (TBBP-A), hexabromocyclododecanes (HBCDs), specific phthalates (DEHP, BBP and DBP), polyvinyl chloride (PVC), and organobromine and organochlorine compounds. They concluded that "less harmful" alternatives to these substances are available and, therefore, substitution is highly recommended. See: GROSS, R., BUNKE, D., GENSCH, C., ZANGI, S., and MANHART, A., note 25 above, p. 48, 62, 87, 179, 195.

${ }^{141}$ For instance, at the recycling sites in Ghana and China, antimony was found, which is a type of heavy metal that persists ad infinitum in the environment. See on this point: KUPER, J., and M., HOJSKIN, note 25 above, p. 16. 
that the illegal export of e-waste can irreversibly damage ecosystems and cause biodiversity loss. The reason for this is clear: scientific studies have already presented valuable empirical evidence about the dangers of heavy metals and chemical compounds. Most of these substances, all in use in electronics manufacturing, are known to have adverse effects on nature because they are persistent, bioaccumulative and identified as endocrine disrupters.

Although the linkage between e-waste and environmental decay is sometimes very clear, it is generally overlooked. Some evidence suggests that shortcomings in the EU Directive on the Restriction of the Use of Certain Hazardous Substances in Electrical and Electronic Equipment (RoHS), the EU Directive on Waste Electrical and Electronic Equipment (WEEE) and the recast proposals could increase the threat posed by e-waste pollution to the environment, especially when e-waste is illegally exported to less industrialized states. The present study drew insights from the scientific literature to illustrate the potential hazards of e-waste pollution to the environment. It aimed to identify potentials and limitations of the RoHS Directive, WEEE Directive and the recast proposals, which could undermine the effectiveness of the legislation as a whole, and lead to increased environmental decay. In this regard, the study contended that the RoHS and WEEE Directives and the recast proposals should not escape critical scrutiny because legal constraints in their provisions could ultimately increase the threat posed by e-waste pollution on biodiversity and ecosystem functioning.

However, more research is needed. Studies should specifically address the relationship between the problem of the illegal export of e-waste to recycling facilities in less industrialized states and the potential damage that e-waste could inflict on local ecosystems and biodiversity. Furthermore, research should review the EU legislation on e-waste since it could have an impact on biodiversity and ecosystem protection not only within the EU but also beyond. The EU legislation on e-waste should also be closely examined to identify whether there are opportunities to make effective reductions in the burden of e-waste pollution. In particular, attention should be paid to the RoHS and the WEEE Directives and the proposals for recasting the two Directives, because this legislation could play an 
essential role in preventing e-waste pollution from becoming a major source of environmental degradation.

\section{BIBLIOGRAPHY}

ALIANI, S., GRIFFA, A., and MOLCARD, A., "Floating debris in the Ligurian Sea, northwestern Mediterranean", Marine Pollution Bulletin, no. 46.9, 2003, pp. 1142-1149.

ANDERSSON, E., Hazardous substances in electrical and electronic equipment (EEE) expanding the scope of the RoHS directive, Project Report, Goteborg University \& Swedish Chemicals Inspectorate, 2005. Retrieved June 2, 2010, from: http://circa.europa.eu/Public/ irc/env/weee_2008/library?1=/characteristics/hazardous_substances/_EN_1.0_\&a=d.

ARLACCHI, P., "Some Observations on Illegal Markets", in RUGGIERO V. (ed.), The New European Criminology: Crime and Social Order in Europe, Routledge, London, 1998, pp. 203- 215.

BABU, B. R., PARANDE, A. K., and BASHA, C.A., "Electrical and electronic waste: a global environmental problem", Waste Management and Research, no. 25.4, 2007, pp. 307318.

BASIlE, A., SORBO, S., APRILE, G., CONTE, B., CASTALDO COBIANCHI, R., PISANI, T., and LOPPI, S., "Heavy metal deposition in the Italian 'triangle of death' determined with the Moss Scorpiurum circinatum", Environmental Pollution, no. 157.8-9, 2009, pp. 2255-2260.

BELLI, B., "Trash Talking”, The Environmental Magazine, March/April 2007, p. 24.

BLEEKER A., "Does the Polluter Pay? The Polluter-Pays Principle in the Case Law of the European Court of Justice”, European Energy and Environmental Law Review, no. 18.6, 2009, pp. 289- 306.

BOGAERT, S. VAN ACOLEYEN, M., VAN TOMME, I., DE SMET, L., FLEET, D., and SALADO, R., Study on RoHS and WEEE Directives, Final Report, Arcadis RPA, Brussels, 
March 2008. Retrieved May 23, 2009, from: http://ec.europa.eu/environment/waste/weee/ pdf/rpa_study.pdf.

BRIGDEN, K., LABUNSKA, I., SANTILLO, D., and JOHNSTON, P., Chemical contamination at e-waste recycling and disposal sites in Accra and Korforidua, Ghana. Greenpeace Research Laboratories, Amsterdam, 2008. Retrieved February 23, 2009, from: http://www.greenpeace.org/international/Global/international/planet-2/report/2008/9/ chemical-contamination-at-e-wa.pdf.

CHEN, D., BI, X., ZHAO, J., CHEN, L., TAN, J., MAI, B., SHENG, G., FU, J., and WONG, M., "Pollution characterization and diurnal variation of PBDEs in the atmosphere of an e-waste dismantling region”, Environmental Pollution, no. 157.3, 2009, pp. 10511057.

CHIDI NNOROMA, I., and OSIBANJOB, O., "Sound management of brominated flame retarded (BFR) plastics from electronic wastes: state of the art and options in Nigeria", Resources, Conservation and Recycling, no. 52, 2008, pp. 1362-1372.

CHRISTEN, K., “Government Watch: EU e-waste rules driving change in United States”, Environmental Science and Technology, no. 37.1, 2003, p. 13.

CLAPP, J., "The toxic waste trade with less-industrialised countries: economic linkages and political alliances", Third World Quarterly, no. 15.3, 1994, pp. 505-518.

COLBORN, T., VOM SAAL, F. S., and SOTO, A. M., "Developmental effects of EDCs in wildlife and humans", Environmental Health Perspective, no. 101, 1993, pp. 378-384.

COMMISSION OF THE EUROPEAN COMMUNITIES, Commission Staff Working Paper accompanying the Proposal for a Directive of the European Parliament and of the Council on the restriction of the use of certain hazardous substances in electrical and electronic equipment (recast), SEC (2008) 2930, Brussels, 3.12.2008. Retrieved September 15, 2009, from: http://eur-lex.europa.eu/LexUriServ/LexUriServ.do?uri=SEC: 2008:2930:FIN:EN:PDF.

COMMISSION OF THE EUROPEAN COMMUNITIES, Commission Staff Working Paper 
accompanying the Proposal for a Directive of the European Parliament and of the Council on waste electrical and electronic equipment (WEEE)(recast), SEC (2008) 2933, Brussels, 3.12.2008. Retrieved September 15, 2009, from: http://eur-lex.europa.eu/LexUriServ/ LexUriServ.do?uri=SEC:2008:2933:FIN:EN:PDF.

COMMISSION OF THE EUROPEAN COMMUNITIES, Proposal for a Directive of the European Parliament and of the Council on waste electrical and electronic equipment (WEEE) (recast), COM (2008) 810 final, Brussels, 2008. Retrieved June 25, 2010 from http://eur-lex.europa.eu/LexUriServ/LexUriServ.do?uri=COM:2008:0810:FIN:en:PDF.

COMMISSION OF THE EUROPEAN COMMUNITIES, Proposal for a Directive of the European Parliament and of the Council on the restriction of the use of certain hazardous substances in electrical and electronic equipment (recast), COM (2008) 809 final, Brussels, 2008. Retrieved June 25, 2010 from. http://eur-lex.europa.eu/LexUriServ/LexUriServ.do? uri=COM:2008:0809:FIN:en:PDF.

CORRILL, L. S., and HUFF, J. E., "Occurrence, physiologic effects, and toxicity of heavy metals-arsenic, cadmium, lead, mercury, and zinc-in marine biota: an annotated literature collection”, Environmental Health Perspectives, no.18, 1976, pp. 181- 183.

COUNCIL OF THE EUROPEAN UNION, Proposal for a Directive of the European Parliament and of the Council on the restriction of the use of certain hazardous substances in electrical and electronic equipment - (RoHS) (recast). Progress Report, 10350/10, Brussels, June 2010. Retrieved October 12, 2010, from: http://register.consilium.europa.eu/ pdf/en/10/st10/st10350.en10.pdf.

COUNCIL OF THE EUROPEAN UNION, Proposal for a Directive of the European Parliament and of the Council on waste electrical and electronic equipment (WEEE) (recast). Progress Report, 10351/10. Brussels, 1.6.2010. Retrieved September 5, 2010, from: http://register.consilium.europa.eu/pdf/en/10/st10/st10351.en10.pdf.

CROSSEN, T., "Multilateral environmental agreements and compliance continuum", Georgetown International Environmental Law Review, no. 16.3, 2004, pp. 473-500.

CROWHURST, G., and DAVIDSON, S., “The New Regulation on Waste Shipment: Green 
List Controls", European Environmental Law Review, no. 16.8/92007, pp. 223- 226.

DE SADELEER, N., and ROOSEVELT, A. F. D., "The Precautionary Principle in EC Health and Environmental Law”, European Law Journal, no 12.2, 2006, pp. 139- 172.

DELBAERE, B., "European policy review-assessing policy impacts on biodiversity", Journal for Nature Conservation, no. 14.2, 2006, pp. 129-130

DERRAIK, J.G.B., "The Pollution of the Marine Environment by Plastic Debris", Marine Pollution Bulletin, no.44.9, 2002, pp. 842-852.

EDINGER, E. N., JOMPA, J., LIMMON, G. V., WIDJATMOKO, W., and RISK, M. J., "Reef degradation and coral biodiversity in Indonesia: effects of land-based pollution, destructive fishing practices and changes over time", Marine Pollution Bulletin, no. 36.8, 1998, pp. 617-630.

ELLIOTT, L., “Combating Transnational Environmental Crime: 'Joined up' thinking about transnational networks", in KAGASPUNTA, K., and I. H., MARSHALL, (eds.), Eco-crime and Justice. Essays on Environmental Crime, Unicri, Turin, 2009, pp. 55-78.

EUROPEAN COMMISSION, Frequently Asked Questions on Directive 2002/95/EC on the Restriction of the Use of certain Hazardous Substances in Electrical and Electronic Equipment (RoHS) and Directive 2002/96/EC on Waste Electrical and Electronic Equipment (WEEE), 2005, p. 12. Retrieved September 11, 2010, from: http://ec.europa.eu/ environment/waste/pdf/faq_weee.pdf.

EUROPEAN ECONOMIC AND SOCIAL COMMITTEE, Opinion of the European Economic and Social Committee on the Proposal for a Directive of the European Parliament and of the Council on Waste electrical and electronic equipment (WEEE), [ 2009] OJ C 306/39, 16.12.2009. Retrieved September 3, 2010, from: http://eurlex.europa.eu/LexUriServ/LexUriServ.do?uri=OJ:C:2009:306:0039:0041:EN:PDF.

EUROPEAN ENVIRONMENTAL AGENCY, Waste without borders in the EU? Transboundary shipment of waste, Luxembourg, 2009. Retrieved November 3, 2009, from http://www.eea.europa.eu/publications/waste-without-borders-in-the-eu-transboundary- 
shipments-of-waste.

EUROPEAN PARLIAMENT-COMMITTEE ON THE ENVIRONMENT, PUBLIC HEALTH AND FOOD SAFETY, Draft Report on the proposal for a directive of the European Parliament and of the Council on waste electrical and electronic equipment (WEEE), 2008/0241(COD), Brussels, 8.2.2010. Retrieved September 11, 2010, from: http:// www.europarl.europa.eu/meetdocs/2009_2014/documents/envi/pr/ 807/807375/807375en.pdf.

EUROPEAN PARLIAMENT- COMMITTEE ON THE ENVIRONMENT, PUBLIC HEALTH AND FOOD SAFETY, Report on the Proposal for a Directive of the European Parliament and of the Council on the restriction of the use of certain hazardous substances in electrical and electronic equipment (recast), A7-0196/2010, 15.6.2008, p. 9. Retrieved July 30, 2010 , from: http://www.europarl.europa.eu/sides/get Doc.do? type $=$ REPORT \& reference $=$ A7-2010-0196\&language $=\mathrm{EN}$

EZROJ, A., "How the European Union's WEEE \& ROJS Directives can help the United States Develop a Successful National E-waste Strategy", Virginia Environmental Law Journal, no. 28, 2010, pp. 45-72.

FOSSI, M. C., CASINI, S., and MARSILI, L., "Endocrine disruptors in Mediterranean top marine predators", Environmental Science and Pollution Research, no. 13.3, 2006, pp. 204 207.

FRENCH, D., "Developing States and International Environmental Law: The Importance of Differentiated Responsibilities", International and Comparative Law Quarterly, no. 49.1, 2008, pp. 35-60.

FREY, R. S., "The hazardous waste stream in the world-system", in Ciccantell, P. S., Bunker, S. G. (eds.), Space and Transport in the World-system, Greenwood Press, Westport, 1998.

FU, J., ZHOU, Q., LIU, J., LIU, W., WANG, T., ZHANG, Q., and JIANG, G., "High levels of heavy metals in rice (Oryza sativa L.) from a typical E-waste recycling area in southeast China and its potential risk to human health", Chemosphere, no. 71.7, 2008, pp. 1269- 


\section{5.}

GENSCH, C., ZANGL, S., and DEUBZER, O., Adaptation to Scientific and Technical Progress under Directive 2002/95/EC, Final Report, Öko-Institut e.V. \& Fraunhofer IZM, Freiburg, 2007, pp. 62- 64. Retrieved July 2, 2010, from: http://ec.europa.eu/environment/ waste/weee/pdf/rohs.pdf

GIBBS, C., Mc GARRELL, E. F., and AXELROD, M., "Transnational white-collar crime and risk", Criminology and Public Policy, no. 9.3, 2010, pp. 543-560.

GOOSEY, M., "End-of-life electronics legislation-an industry perspective”, Circuit World, no. $30.2,2004$, pp. $41-45$.

— "Implementation of the RoHS directive and compliance implications for the PCB sector", Circuit World, no. 33.1, pp. 47-50.

GOTTBERG, A., MORRIS, J., POLLARD, S., MARK-HERBERT, C., and M., COOK, "Producer responsibility, waste minimisation and the WEEE Directive: Case studies in ecodesign from the European lighting sector", Science of the Total Environment, no. 359.1-3, 2006, pp. 38-56;

GROSS, M., DAGINNUS, K., DEVILlER, G., DE WOLF, W., DUNGEY, S., GALLI, C., and GOURMELON, A., "Thresholds of toxicological concern for endocrine active substances in the aquatic environment", Integrated Environmental Assessment and Management, no. 6.1, 2010, pp. 2-11.

GROSS, R., BUNKE, D., GENSCH, C., ZANGI, S., and MANHART, A., Study on Hazardous Substances in Electrical and Electronic Equipment, Not Regulated by the RoHS Directive, Öko- Institut e. V., Freiburg, 2008. Retrieved July 3, 2010, from http://hserohs.oeko.info/fileadmin/user_upload/Documents/Project_description.pdf.

GWAM, C. U., "Adverse Effects of the Illicit Movement and Dumping of Hazardous, Toxic, and Dangerous Wastes and Products on the Enjoyment of Human Rights", Florida. Journal of International Law, no. 14, 2001, pp. 427- 474.

HICKS, C., DIETMAR, R., and EUGSTER, M., "The recycling and disposal of electrical 
and electronic waste in China-legislative and market responses", Environmental Impact Assessment Review, no. 25.5, 2005, pp. 459-471.

HRISTEV, I., "RoHS and WEEE - The new European Directives: Do they work and why (or why not)? Current application and development in the EU and USA", European Environmental Law Review, no. 15.2, 2006, pp. 62- 74.

HOEVELER, J.A., "International approaches to dealing with electronic waste", New Zealand Journal of Environmental Law, no. 13, 2009 pp. 117- 160.

HUISMAN, W., and VAN ERP, J., "Smart Regulation and Enforcement of Illegal Disposal of Electronic Waste", Criminology and Public Policy, no. 9.3, 2010, pp. 579-590.

HYLANDER, L. D., and GOODSITE, M. E., "Environmental costs of mercury pollution", Science of the Total Environment, no. 368.1, 2006, pp. 352-370;

ILES, A., "Mapping environmental justice in technology flows: Computer waste impacts in Asia”, Global Environmental Politics, no. 4.4, 2004, pp. 76-107.

INTERPOL, "Electronic waste and organized crime-assessing the links", Trends in Organized Crime, no. 12, 2009, pp. 352-378.

JANG, M., HONG, S. M., and PARK, J. K., "Characterization and recovery of mercury from spent fluorescent lamps", Waste Management, no. 25.1, 2005, pp. 5-14.

JANS, J.H., and VEDDER, H. H. B., European Environmental Law, $3^{\text {rd }}$ ed., Europa Law Publishing, Groningen, 2008.

KELLNER, R., "Integrated Approach to Electronic Waste (WEEE) Recycling”, Circuit World, no. 33.2, 2009, pp. 52- 58.

KHETRIWAL, D. S., KRAEUCHI, P., and WIDMER, R., "Producer responsibility for ewaste management: Key issues for consideration-Learning from the Swiss experience", Journal of Environmental Management, no. 90.1, 2009, pp. 153-165.

KUPER, J., and HOJSKIN, M., Poisoning the Poor. Electronic Waste in Ghana, Greenpeace Research Laboratories, Amsterdam, 2008. Retrieved February 23, 2009, from 
http://www.greenpeace.org/raw/content/international/press/reports/poisoning-the-poorelectonic.pdf.

LAÏDI, Z., EU foreign policy in a globalized world: normative power and social preferences, Routledge, Abingdon, 2008.

LEGLER J., BROUWER, A., “Are brominated flame retardants endocrine disruptors?", Environmental International, no. 29.6, 2003, pp. 879-885.

LI, J., TIAN, B., LIU, T., LIU, H., WEN, X., and HONDA, S., "Status quo of e-waste management in mainland China", Journal of Material Cycles and Waste Management, no. 8.1, 2006, pp. 13-20.

LIPMAN, Z. “A Dirty Dilemma: The Hazardous Waste Trade”, Harvard International Review, no. 23.4, 2002, pp. 67-71.

LIU, H., ZHOU, Q., WANG, Y., ZHANG, Q., CAI, Z., and JIANG, G., "E-waste recycling induced polybrominated diphenyl ethers, polychlorinated biphenyls, polychlorinated dibenzo-p-dioxins and dibenzo-furans pollution in the ambient environment", Environment International, no. 34.1, 2008, pp. 67-72.

LYNCH, M. J., and MICHALOWSKI, J. R., Premier in Radical Criminology: Critical Perspective on Crime, Power and Identity, Criminal Justice Press, Monsey, 2006.

MADAVA, T., "Illicit dumping of toxic wastes breach of human rights", Review of African Political Economy, no. 28.88, 2001, pp. 288-290.

MANOMAIVIBOOL, P., "Extended producer responsibility in a non-OECD context: The management of waste electrical and electronic equipment in India", Resources, Conservation and Recycling, no. 53, 2009, pp. 136-144.

MARTINEZ, C., "EEE Waste and the Basel Convention", in United Nations Conference on Trade and Development, Trade and Environment Review, UNCTAD, Geneva, 2006, pp. $92-$ 95.

MASElLI, V., POLESE, G., RIPPA, D., LIGRONE, R., KUMAR RASTOGI, R., and FULGIONE, D., "Frogs, sentinels of DNA damage induced by pollution in Naples and the 
neighbouring provinces", Ecotoxicology and Environmental Safety, no. 73.7, 2010, pp. $1525-1529$.

MAXIANOVA, K., "Shipment of Electronic Waste: Providing the Right Incentives through Regulation and Enforcement", Review of European Community and International Environmental Law, no. 17.3, 2008, pp. 270- 278.

MAXIM, L., and SPANGENBERG, J. H., "Driving forces of chemical risks for the European biodiversity", Ecological Economics, no. 69.1, 2009, pp. 43-54.

MCKENNA, A., "Computer waste: a forgotten and hidden side to the global information society", Environmental Law Review, no. 9, 2007, pp. 116- 131.

MOCK, D., and PERINO, G., "Wasting innovation: barriers to entry and European regulation on waste electronic equipment", European Journal of Law and Economics, no. 26.1, 2008, pp. 1- 10 .

MORF, L. S., TREMP, J., GLOOR, R., HUBER, Y., STENGELE, M., and ZENNEGG, M., "Brominated flame retardants in waste electrical and electronic equipment: substance flows in a recycling plant”, Environmental Science and Technology, no. 39.22, 2005, pp. 8691-8699.

MUENHOR, D., HARRAD, S., ALI, N., and COVACI, A., "Brominated flame retardants (BFRs) in air and dust from electronic waste storage facilities in Thailand", Environment International, no. 36.7, 2010, pp. 690- 698

MUKHERJEE, A. B., ZEVENHOVEN, R., BRODERSEN, J., HYLANDER, L. D., and BHATTACHARYA, P., "Mercury in waste in the European Union: sources, disposal methods and risks", Resources, Conservation and Recycling, no. 42.2, 2004, pp. 155-182.

MUNDADA, M. N., KUMAR, S., and SHEKDAR, A. V., "E-waste: a new challenge for waste management in India", International Journal of Environmental Studies, no. 61(3), 2004, pp. 265-279.

NI, H. G., ZENG, H., TAO, S., and ZENG, E. Y., "Environmental and human exposure to persistent halogenated compounds derived from e-waste in China", Environmental 
Toxicology and Chemistry, no. 29.6, 2010, pp. 1237-1247.

NICOL, S., and THOMPSON, S., "Policy options to reduce consumer waste to zero: comparing product stewardship and extended producer responsibility for refrigerator waste", Waste Management and Research, no. 25.3, 2007, pp. 227- 233.

O’ ROURKE, M., “Killer Computers: The Growing Problem of E-Waste”, Risk Management, no. 51.10, 2004, pp. 12- 18.

ORGANIZATION FOR ECONOMIC CO-OPERATION AND DEVELOPMENT, Extended Producer Responsibility. A Guidance Manual for Governments, Paris, OECD, 2003.

OETKEN, M., BACHMANN, J., SCHULTE-OEHLMANN, U., and OEHLMANN, J., "Evidence for endocrine disruption in invertebrates", International Review of Cytology, no. 236, 2004, pp. 1-44.

PAKAlin, S., COLE, T., STEINKELLNER, J., NICOLAS,R., TISSIER,C., MUNN, S., and EISENREICH, S., Review on Production Process of Decabromodiphenyl Ether (DecaBDE) Used in Polymeric Applications in Electrical and Electronic Equipment amd Assessment of the Availability of Potential Alternatives to DecaBDE, European Chemicals Bureau, 2007. Retrieved July 2, 2010, from: http://ecb.jrc.it/documents/ExistingChemicals/Review_on_production_process_of_decaBDE.pdf

PASSAS, N., "Lawful but awful: Legal Corporate Crimes", Journal of Socio-Economics, no. $34.6,2005$, pp. 771-786.

PETERSEN, G., RASMUSSEN, D., and GUSTAVSON, K., Study on enhancing the Endocrine Disrupter priority list with a focus on low production volume chemicals, European Community - DG Environment, 2007. Retrieved July 10, 2010 from http:// ec.europa.eu/environment/endocrine/documents/final_report_2007.pdf.

PLAMBECK, E., WANG, Q., “Effects of e-waste regulation on new product introduction”, Management Science, no. 55.3, 2009, pp. 333-347.

PRAKASH, C., "Chromium Accumulation and Toxicity in Aquatic Vascular Plants", The 
Botanical Review no. 70.3, 2004, pp. 313-327.

PUCKETT, J., BYSTER, L., WESTERVELT, S., GUTIERREZ, R., DAVIS, S., HUSSAIN, A., and DUTTA, M., Exporting harm: the high-tech trashing of Asia, Basel Action Network and Silicon Valley Toxics Coalition, Seattle, 2002. Retrieved November 4, 2009, from http://www. ban. org/E-waste/technotrashfinalcomp.pdf.

REBECHINI, H. M., and HANZELY, L., "Lead-induced ultrastructural changes in chloroplasts", Z. Pflanzenphysiol, no. 73, 1974, pp. 377-386.

REDFORD, K. H, and RICHTER, B. D., "Conservation of biodiversity in a world of use", Conservation Biology, no. 13.6, 1999, pp. 1246-1256.

ROBINSON, B. H., "E-waste: An assessment of global production and environmental impacts", Science of the Total Environment, no. 408.2, 2009, pp. 183-191.

ROLLER, G., and FÜHR, M., "Individual Producer Responsibility: A Remaining Challenge under the WEEE Directive", Review of European Community and International Environmental Law, no. 17.3, 2008, pp. 279- 285.

ROTLLANT, G., ABAD, E., SARDĀ, F., ÁBALOS, M., COMPANY, J.B., and RIVERA, J., "Dioxin compounds in the deep-sea rose shrimp Aristeus antennatus (Risso, 1816) throughout the Mediterranean Sea", Deep Sea Research Part I: Oceanographic Research Papers, no. 53.12, 2006, pp. 1895-1906.

RUGGIERO, V., Organized and Environmental Crime in Europe. Offers that Can't Be Refused, Aldershot, Dartmouth, 1996.

SACHS, N., "Planning the funeral at the birth: extended producer responsibility in the European Union and the United States", Harvard. Environmental Law Review, no. 30, pp. 51-98.

SÁNCHEZ-CHARDI, A., PEÑARROJA-MATUTANO, C., OLIVEIRA RIBEIRO C. A., and NADAL, J., "Bioaccumulation of metals and effects of landfill pollution in small mammals. Part II. The wood mouse, Apodemus sylvaticus", Chemosphere, no. 68.4, 2007, pp. $703-711$. 
SANDER, E., TOJO, K., VERNON, N., SCHILlING, J., VAN ROSSEN, S., and GEORGE, C., The Producer Responsibility Principle of the WEEE Directive, European Community, DG Environment, 2007. Retrieved August 3, 2010 from http://ec.europa.eu/ environment/waste/weee/pdf/final_rep_okopol.pdf.

SANDER, K., and SCHILLING, S., Transboundary shipment of waste electrical and electronic equipment/ electronic scrap - Optimization of material flows and control. Ökopol GmbH, Hamburg, 2010. Retrieved July 26, 2010, from http:/www.basel.int/ techmatters/e_wastes/germany-report-18May2010.pdf.

SANDS, P., "European Community environmental law: the evolution of a regional regime of international environmental protection", Yale Law Journal, no. 100.8, 1991, pp. 25112523.

SCHMIDT, A., "Transboundary Movements of Waste Under EC Law: The Emerging Regulatory Framework”, Journal of Environmental Law, 4.1, 1992, pp. 57- 80.

SELIN, H., and VAN DEVEER, S. D., "Raising Global Standards: Hazardous substances and e-waste management in the European Union", Environment: Science and Policy for Sustainable Development, no. 48.10, 2006, pp. 6-18.

SEPÚlVEDA, A., SCHLUEP, M., RENAUd, F. G., STREICHER, M., KUEHR, R., HAGELÜKEN, C., and GERECKE, A. C., "A review of the environmental fate and effects of hazardous substances released from electrical and electronic equipments during recycling: Examples from China and India", Environmental Impact Assessment Review, no. $30.1,2010$, pp. 28-41.

SHELTON, D., and KISS, A., Guide to International Environmental Law, Martinus Nijhoff Publishers, Leiden, 2007.

SHINKUMA, T., and THI MINH HUONG, N., "The Flow of E-waste Material in the Asian Region and a Reconsideration of International Trade Policies on E-waste", Environmental Impact Assessment Review, no. 29.1, 2009, pp. 25-31.

SKINNER, I., BEYER, P., and FARMER, A., Effective Enforcement Needs a Good Legal 
Base: the Final Report of the IMPEL Better Legislation Project, European Union Network for the Implementation and the Enforcement of Environmental Law, 2005. Retrieved November 2, 2009, from http://impel.eu/wp-content/uploads/2010/02/2003-13-principlesbetter-legislation-FINAL-REPORT.pdf.

SLADE, G., Made to break: technology and obsolescence in America, Harvard University Press, Cambridge, 2006.

SMITH, J.A., WITKOWSKI, P.J., and FUSILLO, T. V., Manmade organic compounds in the surface waters of the United States - A review of current understanding, Geological Survey Circular, Denver, 1990.

UMESI, N. O., and ONYIA, S., "Disposal of e-wastes in Nigeria: an appraisal of regulations and current practices", International Journal of Sustainable Development and World Ecology, no. 15.6, 2008, pp. 565-573.

UNITED NATIONS UNIVERSITY, 2008 Review of Directive 2002/96/EC on Waste Electrical and Electronic Equipment: Final Report, Bonn, 2007, Retrieved May 4, 2009, from http://ec.europa.eu/environment/waste/weee/pdf/final_rep_unu.pdf.

VAN CALSTER, G., Handbook of EU Waste Law, Richmond Law \& Tax, Richmond, 2006.

WIDAWSKY, L., "In my backyard: How Enabling hazardous waste trade to developing nations can improve the Basel Convention's ability to achieve environmental justice", Environmental Law, no. 38, pp. 577-625.

WIDMER, R., OSWALD-KRAPF, H., SINHA-KHETRIWAL, D., SCHNELLMANN, M., and BOENI, H., "Global perspectives on e-waste", Environmental Impact Assessment Review, no. 25.5, 2005, pp. 436-458.

WONG, C. S., DUZGOREN-AYDIN, N. S., AYDIN, A., and WONG, M. H., "Evidence of excessive releases of metals from primitive e-waste processing in Guiyu, China", Environmental Pollution, no. 148.1, 2007, pp. 62-72.

WONG, C. S., DUZGOREN-AYDIN, N. S., AYDIN, A., and WONG, M. H., "Sources and 
trends of environmental mercury emissions in Asia", Science of the Total Environment, no. 368.2-3, 2006, pp. 649-662.

WONG, C. S., WU, S. C., DUZGOREN-AYDIN, N. S., AYDIN, A., and M. H., WONG, "Trace metal contamination of sediments in an e-waste processing village in China", Environmental Pollution, no. 145.2, 2007, pp. 434-442.

WONG, M. H., WU, S. C., DENG, W. J., YU, X. Z., LUO, Q., LEUNG, A. O. W., WONG, C. S. C., LUKSEMBURG, W.J., and WONG, A.S., "Export of toxic chemicals - A review of the case of uncontrolled electronic-waste recycling”, Environmental Pollution, no. 149.2, 2007, pp. 131-140.

WORLD HEALTH ORGANIZATION, Guidelines for drinking-water quality. Health criteria and other supporting information, $2^{\text {nd }}$ Edition, Vol. 2, WHO, Geneva, 1996.

WATSON, E., and CROWHURST, G., "The Implementation of the WEEE Directive in the UK - A critical Analysis”, European Environmental Law Review, no. 16.6, 2007, pp. 163175.

YU, X., "Biodiversity conservation in China: barriers and future actions", International Journal of Environmental Studies, no. 67.2, 2010, pp.117-126. 